\title{
The lichens of the northern shore of the Gulf of Finland in the limits of St. Petersburg, Russia - diversity on the edge of the megapolis
}

\author{
Irina S. Stepanchikova ${ }^{1,2}$, Dmitry E. Himelbrant ${ }^{1,2}$, Ekaterina S. Kuznetsova ${ }^{1,2}$, Jurga \\ Motiejūnaitė $^{3}$, Sergey V. Chesnokov ${ }^{2}$, Liudmila A. Konoreva ${ }^{2,4}$, Ludmila V. Gagarina ${ }^{2}$ \\ ${ }^{1}$ St. Petersburg State University, Universitetskaya emb. 7-9, 199034 St. Petersburg, Russia. \\ E-mails: stepa_ir@mail.ru, d_brant@mail.ru, igel_kuzn@mail.ru \\ ${ }^{2}$ Laboratory of Lichenology and Bryology, Komarov Botanical Institute RAS, Professor Popov St. 2, 197376 St. \\ Petersburg, Russia. E-mail: lukinbrat@mail.ru, gagarinalv@binran.ru \\ ${ }^{3}$ Laboratory of Mycology, Institute of Botany, Nature Research Centre, Žaliujų Ežerų 49, LT-08406 Vilnius, Lithuania. \\ E-mail: jurga.motiejunaite@gamtc.lt \\ ${ }^{4}$ Polar-alpine Botanical Garden-Institute, 184250 Murmansk Region, Kirovsk. E-mail: ajdarzapov@yandex.ru
}

\begin{abstract}
We present a lichen checklist for the northern shore of the Gulf of Finland in the limits of St. Petersburg, Russia. This area has diverse lichen biota within the city limits, and has been comprehensively studied since 1893, which gives a good base for analysis of historical changes in lichen diversity. The documented lichen biota comprises 469 species (430 lichenized, 24 lichenicolous, 3 facultatively lichenicolous, and 12 non-lichenized saprobic fungi), of them 191 species are known from herbaria and literature for the period before 1991, and 436 species were recorded since 1991 to 2019. Thirty-three taxa were excluded from the lichen list of the study area as erroneous or dubious records. Altogether 48 species are new to St. Petersburg, including: Lecidea malmeana and Micarea czarnotae - new to Russia; Caloplaca lucifuga, Gyalecta nigricans, Micarea soralifera - new to European Russia; Agonimia flabelliformis, Endococcus verrucosus, Lecania turicensis, Micarea fallax, M. tomentosa, Xanthomendoza huculica - new to Northwestern European Russia; Lichenoconium lichenicola, Ramalina europaea, Sarcogyne hypophaea - not known also from the Leningrad Region. The studied lichen biota is moderately rich compared to other city territories. The history of economic development of the region has caused its serious transformation, degradation of natural habitats and therefore partial loss of lichen diversity. At the same time, human-made substrates and anthropogenic plant communities are inhabited by lichens, including species unknown in the natural habitats of the study area. However, 44 species recorded in the study area are red-listed in St. Petersburg, with 13 of them known only from historical collections. Forest communities, as well as historical parks, in NW part of St. Petersburg are important source of biodiversity on regional level nowadays and hopefully in future, and deserve protection.
\end{abstract}

Keywords: Isthmus karelicus, black alder communities, indicator species, protected areas, Caloplaca lucifuga, Gyalecta nigricans, Lecidea malmeana, Micarea czarnotae, Micarea soralifera

\section{INTRODUCTION}

The northern shore of the Gulf of Finland (Baltic Sea) in the limits of St. Petersburg is a part of the city, one of the most diverse and interesting areas in terms of landscapes and biocenoses. Moreover, the lichens of this territory were actively investigated earlier, and this gives a good possibility for evaluation of historical changes.

The first known collections of lichens from the study area were made by Finnish scientists A. O. Kihlman in 23-27.10.1893 (49 specimens from vicinities of Serovo, former Vammelsuu; see Stepanchikova et al., 2014) and H. Lindberg in 25.10.1893 (a specimen of Ramalina farinacea from Sestroretsk) and now are kept mainly in the lichen herbarium of the Finnish Museum of Natural History, University of Helsinki (H).
During 1898-1919, a considerable and diverse material was collected by Russian biologists I. A. Beketov, V. A. Dubyansky, A. A. Elenkin (AE), B. O. Kashmensky, K. S. Merezhkowsky, K. A. Rassadina, V. P. Savicz, N. V. Shipchinsky, I. A. Vereitinov, and N. N. Voronikhin (see years, territories, herbaria and references in Appendix 1). Subsequent studies of Finnish and Swedish specialists and collectors (S. Ahlner, L. Fagerström, I. Hiitonen (Hiden), M. Laurila, B. Lemberg, L. Räsänen, V. Räsänen, and R. Tuomikoski) in 1924-1941 also resulted in a bulk of remarkable records. During and long after the WWII no special inventories of the lichen diversity of St. Petersburg were conducted, therefore, the period of 1942-1979 resulted in only a few scattered 
collections (27 specimens of trivial species) by Russian and Estonian lichenologists (E. F. Florovskaya, E. N. Moiseeva, E. Nilson, V. P. Savicz, I. A. Shapiro, E. Shtukenberg, H. Trass) and other persons, probably students (Evrikhov, Shalyapina, I. Tikhomirova, Zolotareva). An overall outcome of the first 100 years of investigations (within the study area) included 350 specimens by 30 collectors, and 136 species published in 26 papers and books.

After 1990, a new period of active regional lichen studies started in St. Petersburg and Leningrad Region. The lichen diversity of the northern shore of the Gulf of Finland was investigated since 1995 by O. A. Kataeva, N. V. Malysheva, and S. V. Sokolova, several specimens were also collected in 38 by T. Ahti. Since 2005, D. E. Himelbrant (DH), I. S. Stepanchikova (IS), and E. S. Kuznetsova (EK) have studied exhaustively local lichen biotas of existing and proposed protected areas (PA) within the northern shore of the Gulf of Finland in the limits of $\mathrm{SPb}$, with participation of A. V. Dyomina (AD), L. V. Gagarina (LG), L. A. Konoreva (LK), E. I. Rozantseva (ER), and G. M. Tagirdzhanova (GT). Altogether nine key territories were investigated comprehensively, while results of only two of these inventories have been published (Stepanchikova et al., 2008, 2010a, b, 2014; Pykälä et al., 2012; Himelbrant et al., 2015; Red..., 2018; Appendix 1). In total, the lichenological studies since 1893 to nowadays have resulted in 420 species (excluded taxa are not accounted) published in 46 scientific papers and books, and more than 920 specimens by 47 collectors have been stored in 10 herbaria (BILAS, FH, GZU, H, LE, LECB, S, TU, TUR-V, UPS).

The present paper is the summarized result of 15 years of field investigations and the critical revision of all known herbarium collections and literature records from the northern shore of the Gulf of Finland in the limits of St. Petersburg.

\section{STUDY AREA}

The study area occupies parts of Kurortny and Primorsky districts of St. Petersburg and is bordered by the shoreline of the Gulf of Finland and Primorskaya railway, including also two small in-shore islets Onok and Verperluda. The territory is stretched out along the seashore for ca.
$58 \mathrm{~km}$ and varies in width from c. $540 \mathrm{~m}$ to 3 $\mathrm{km}$ (Fig. 1). The total area of this territory is ca. $92 \mathrm{~km}^{2}$. The NW part of the study area (Kurortny District part) lies almost entirely within Isthmus karelicus (Ik), a biogeographical province of the Eastern Fennoscandia in traditional understanding (Kotiranta et al., 1998). The whole study area has historically been and nowadays still is a resort zone, where St. Petersburg citizens usually spend weekends and holidays.

The relief of this part of St. Petersburg is formed by a relict sedimentary terrace - sandy shore of ancient Littorina Sea. Littorina terrace in SE part of the study area is represented by seashore low flatland, with heights between 0-8 $\mathrm{m}$ a.s.1., whereas in NW part it has local uplands like dunes or glacial sandy hills, and near Serovo the terrace becomes high (up to a maximum of $28 \mathrm{~m}$ a.s.1.) and steep (Isachenko, 1998; Khramtsov et al., 2016). NW part of the study area is mainly covered by pine forests on sand, sometimes peatbogs, more rarely by spruce and deciduous (parvifoliate) forests. In contrast, the SE part is dominated by black alder and parvifoliate forests on clayey soil, spruce and pine forests are rare and have more limited distribution. Currently, all forests are secondary and young, and, together with the seashore, peatbogs, and dune communities are heavily transformed by long-term anthropogenic activity. Main part of the territory today is occupied by small towns, settlements, resorts, parks, industrial areas, roads, and power lines.

\section{MATERIAL AND METHODS}

The material was collected in different parts of the territory from 2005 to 2019 by IS, DH, and EK with the participation of AD, LG, LK, ER, and GT. Altogether nine key territories with 230 localities were investigated (Appendix; Fig. 1): 155 standard sample areas (SA) of $20 \times 20$ $\mathrm{m}$ (or within natural boundaries of the community if the community covered smaller area), where the lichen diversity of each substrate was described comprehensively, and 75 additional plots (AP), where only individual substrates or species were checked. The list of studied territories (Appendix 1) includes also the areas investigated by other collectors, and provides a short description, geographical coordinates, list of visited biotopes, list of collectors, herbaria 


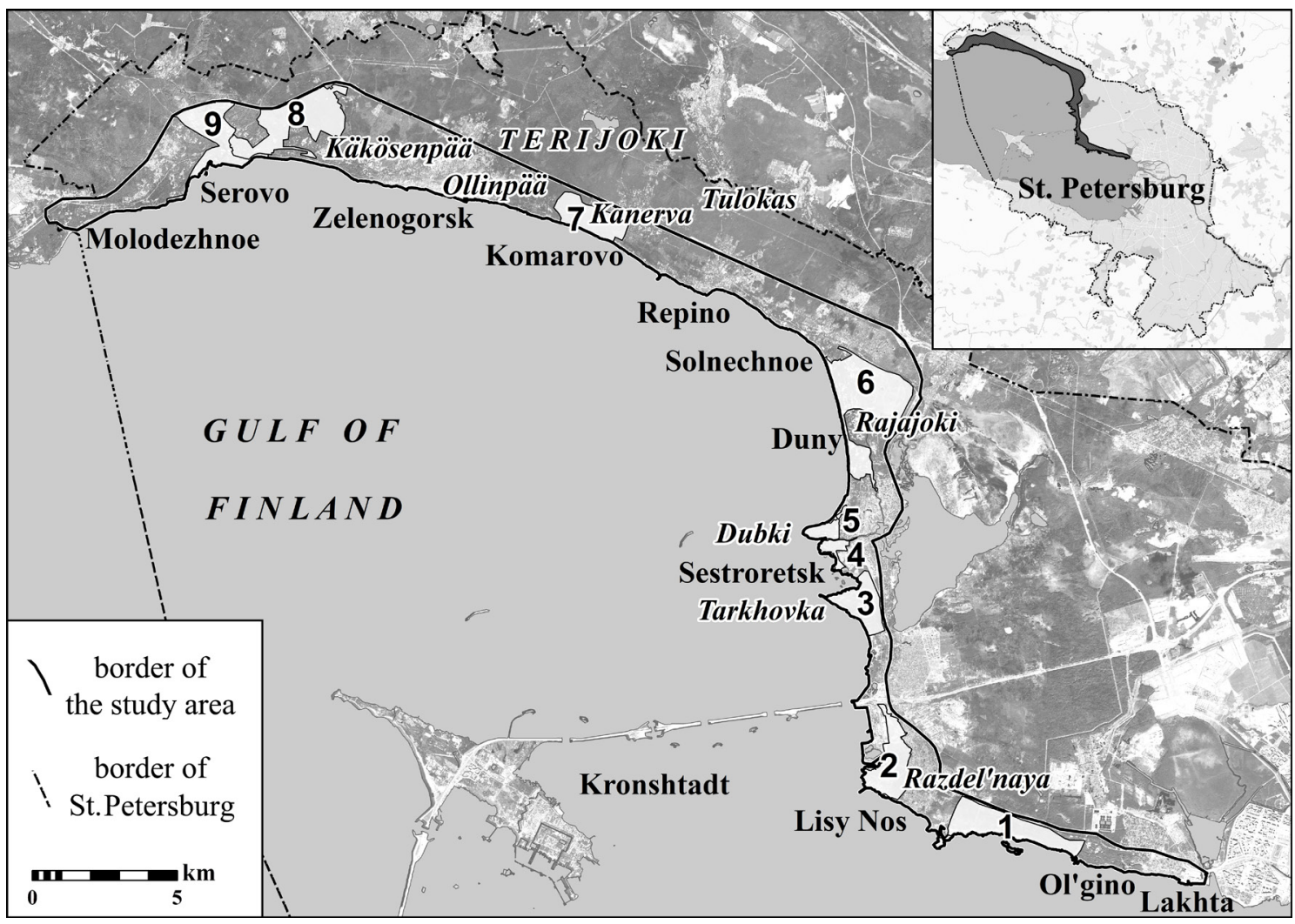

Fig. 1. The study area, northern shore of the Gulf of Finland in the limits of St. Petersburg, with the location of investigated key territories (1-9, see Appendix 1).

and literature references for each territory. The specimens are deposited in H, LE, LECB, and BILAS. IS, DH, and EK identified the majority of the specimens, Jurga Motiejūnaite identified lichenicolous fungi, Sergey V. Chesnokov and LK identified most specimens of Micarea, LG identified or confirmed critical specimens of gyalectoid lichens; if otherwise, the identifier is indicated in the species list.

In the species list the nomenclature of taxa generally follows Nordin et al. (2011), Hafellner $\&$ Türk (2016), Diederich et al. (2018), and Lawrey \& Diederich (2018). For each species the substrates and territories are listed. For the species new to St. Petersburg, or known in the study area from single or no current localities, more detailed information is provided. Species new to St. Petersburg (and not known in Leningrad Region) or larger regions are supplied with information on diagnostic characteristics and distribution in Northwestern European Russia, Fennoscandia and the Baltic countries. Lichen substances are given for HPTLC-analyzed species reported as new to the study area. Chromatography was performed mainly by IS and DH, or LK and Sergey V. Chesnokov (Micarea spp.) according to standard techniques of high performance thin-layer chromatography using solvent systems A, B, and C (Orange et al., 2001).

In the species list the following symbols and abbreviations are used:

(a) fungus types: \# - lichenicolous and algicolous fungi, (\#) - facultatively lichenicolous fungi, + - non-lichenized fungi;

(b) valuable species: ! - regionally protected species (Red..., 2018), § - habitat specialists, * - indicator species (Andersson et al., 2009), $\dagger-$ species known from historical data only; 
(c) regions: LR - Leningrad Region, ELR - Eastern Leningrad Region, WLR - Western Leningrad Region, $\mathrm{SPb}$ - St. Petersburg;

(d) frequency of occurrence for the species collected in 2005-2019 by the authors: $\left[R_{1}\right]$ - single record (the species was found once), $[R]$ - rare (the species was recorded in 2-30 SA, i.e. up to $20 \%$ of the total number of SA or more than in one additional plot), [O] - occasionally (in 31-61 SA, up to $40 \%$ ), [F] - frequent (in 62-92 SA, up to $60 \%$ ), [C] - common (in 93-123 SA, up to 80\%), [VC] - very common (in 124-154 SA, over 80\%);

(e) abbreviations of the collectors' names - see the Introduction.

\section{THE SPECIES}

ABSCONDitella Lignicola Vězda $\&$ Pišút - on wood; $1-3,6-9[R]$.

ABsconditella SPHAGNorum Vězda \& Poelt - 6: $60^{\circ} 07^{\prime} 54.3^{\prime \prime} \mathrm{N}, 29^{\circ} 58^{\prime 2} 26.2^{\prime \prime} \mathrm{E}$, pine and birch stand on drained and burnt bog, on dead mosses, 20.04.2018, leg. EK \& IS (H s. n.) $\left[\mathrm{R}_{1}\right]$.

ACAROSPORA FUSCATA (Schrad.) Th. Fr. - on granite; $1-3,6,8,9$ [R].

ACAROSPORA GLAUCOCARPA (Ach.) Körb. - on concrete; $1,3,4,8,9[\mathrm{R}]$.

ACAROSPORA MOENIUM (Vain.) Räsänen - on concrete; $1-4,8,9$ [R].

ACAROSPORA VERONEnsis A. Massal. - on granite; $2,3[R]$.

!§ Acrocordia cavata (Ach.) R. C. Harris - 2: $60^{\circ} 00^{\prime} 50.2^{\prime \prime} \mathrm{N}, 2^{\circ} 57^{\prime} 50.8^{\prime} \mathrm{E}$, aspen stand on earthen rampart, on bark of Populus tremula, 21.05.2018, leg. DH \& IS (LECB s. n.) $\left[\mathrm{R}_{1}\right]$.

Agonimia allobata (Stizenb.) P. James - 4: $60^{\circ} 04^{\prime} 43.6^{\prime \prime} \mathrm{N}, 29^{\circ} 56^{\prime} 40.5^{\prime \prime} \mathrm{E}$, seashore black alder forest, on bark of Alnus glutinosa, 05.05.2018, leg. DH, EK \& IS (LECB s. n.) $\left[\mathrm{R}_{1}\right]$. New to $\mathrm{SPb}$, previously known from WLR (Himelbrant, Andersson, 2008).

Agonimia flabelliformis Halda et al. - 2: $60^{\circ} 00^{\prime 3} 5.3$ ”N, 2958'35.6”E, swampy deciduous forest with spruces, on old iron military construction, 20.05.2018, leg. DH, EK \& IS (LECB s. n.); 4: 6005’09.0”N, 2955'57.9”'E, swampy seashore black alder forest, on bark of Salix sp., 06.05.2018, leg. DH, EK \& IS (H s. n.); [R]. New to Northwestern European Russia, the nearest locality in the European
Russia is in the Tver' Region (Notov et al., 2019). Distribution in Fennoscandia and Baltic countries: Lithuania (Motiejūnaite, 2017). Differs from other species of the genus by the thallus consisting of very typical flabelliform or coralloid squamules (GuzowKrzemińska et al., 2012). Our specimens are represented by sterile thalli.

Agonimia gelatinosa (Ach.) M. Brand \& Diederich - on soil; 1 (Stepanchikova et al., 2008) [ $\left.R_{1}\right]$. AlyXoria VARIA (Pers.) Ertz \& Tehler - 8: $60^{\circ} 11^{\prime} 49.5^{\prime \prime N}, 29^{\circ} 33^{\prime} 35.2^{\prime \prime E}$, poplar alley on the top of the slope, on bark of Populus sp., 01.05.2016, leg. DH \& IS (LECB s. n.) [R R $_{1}$; 23: 1900, leg. AE (LE L-12531, sub Bacidia fraxinea).

Amandinea CACUminum (Th. Fr.) H. Mayrhofer \& Sheard - 3: 6003'47.3”N, 2957'28.9” E, granite boulders on the seashore, on granite, 30.04.2018, leg. DH \& IS (LECB s. n.) [R $]$. New to $\mathrm{SPb}$, previously known from WLR (Stepanchikova et al., 2019).

AmandinEa PUNCTATA (Hoffm.) Coppins \& Scheid. on bark of deciduous trees and wood, rarely on granite; 1-5, 7-9 [R]; 21, 24, 33 .

! ANAPTYCHIA CILIARIS (L.) Körb. - on bark of Populus spp. and Sorbus aucuparia; 8, 9, 13 [R]; 18, 24, 29, 30.

$\S$ ANISOMERIDIUM BIFORME (Borrer) R. C. Harris - on bark of Populus balsamifera; 11 (Kataeva, 2002 , 2004). No specimens found, but the species is known from other localities in Karelian Isthmus (Harris, 1995; H).

ANISOMERIDIUM POLYPORI (Ellis \& Everh.) M. E. Barr - on bark of deciduous trees and shrubs, on wood of conifers, once on iron; 1-9 [O].

! Arctoparmelia centrifuga (L.) Hale - 8: $60^{\circ} 13^{\prime} 09^{\prime \prime} \mathrm{N}, 29^{\circ} 37^{\prime} 00^{\prime} \mathrm{E}$, disturbed pine forest with mosses, on granite, 06.06.2010, $\mathrm{DH}, \mathrm{EK} \& \mathrm{IS}$ (field record) $\left[\mathrm{R}_{1}\right]$. Erroneously reported from 14 by Malysheva $(1999,2003)$ (see Red..., 2018).

Arthonia apatetica (A. Massal.) Th. Fr. - on smooth bark of Acer platanoides, Alnus incana, Padus avium, Salix sp., Sorbus aucuparia and shrubs; 2, 3, 7-9 [R].

\# ARthonia Biatoricola Ihlen \& Owe-Larss. - 8: $60^{\circ} 12^{\prime} 09.9^{\prime \prime} \mathrm{N}, 2^{\circ} 35^{\prime} 17.6^{\prime \prime} \mathrm{E}$, mixed forest on slope, on thallus of Biatora efflorescens on bark of Alnus incana, 03.05.2016, leg. DH \& IS (LECB s. n.) $\left[\mathrm{R}_{1}\right]$. New to $\mathrm{SPb}$, previously known from WLR (Stepanchikova et al., 2013). 
ARthonia didyma Körb. - 7: 60¹1'11"N, $29^{\circ} 45^{\prime} 49^{\prime \prime} \mathrm{E}$, mixed forest with Alnus glutinosa, on bark of Acer platanoides, 07.05.2017, leg. DH \& IS (LECB s. n.) [ $\left.\mathrm{R}_{1}\right]$; 34: on bark of Picea abies (Stepanchikova et al., 2014).

ARTHONIA DISPERSA (Schrad.) Nyl. - on bark of Acer platanoides; 1 (Stepanchikova et al., 2008) $\left[R_{1}\right]$.

ARTHONIA DISPUNCTA Nyl. - on bark of Acer platanoides, Betula sp., Sorbus aucuparia; 1, 3, 7, 9 [R].

ARthonia FUSCA (A. Massal.) Hepp - on concrete; $8,9[R]$.

!*ARTHOnia Helvola (Nyl.) Nyl. - on bark of Alnus spp., Betula sp., Padus avium, Picea abies, Quercus robur, Salix sp., wood of Pinus sylvestris; 1-9 [R]; 34.

ARTHONIA MEDIELLA Nyl. - on bark of Acer platanoides, Alnus spp., Betula sp., Populus spp., Quercus robur, Salix sp., Sorbus aucuparia, wood of Pinus sylvestris; 1-5, 8, 9 [R].

ARTHONia Patellulata Nyl. - on bark of Populus tremula; $1-4,8,9[\mathrm{R}]$.

+ ARTHONIA PUNCTIFORMIS Ach. - on bark of Alnus spp., Betula sp., Populus tremula, Quercus robur, Salix sp., Sorbus aucuparia, Tilia sp., Ulmus sp.; 1-9 [R].

ARTHONIA RADIATA (Pers.) Ach. - on bark of Acer platanoides, Alnus spp., Corylus avellana, Sorbus aucuparia, Tilia sp.; 1, 2, 5, 6, 8, 9 [R]; 21, 29, 34, 35, 37, 38.

ARthonia RUANA A. Massal. - on smooth bark of deciduous trees; 1-9 [R]; 21.

!* ARTHOnia Spadicea Leight. - on bark of Acer platanoides, Alnus glutinosa, Betula sp., Picea abies, Pinus sylvestris, Quercus robur, Sorbus aucuparia, wood of Pinus sylvestris and Quercus robur, 1-3, 5, 7 [R].

\# $\dagger$ ARthonia subfuscicola (Linds.) Triebel on apothecia of Lecanora carpinea; 34 (Stepanchikova et al., 2014).

ARTHOPYRENIA SALICIS A. Massal. - on bark of Sorbus aucuparia; 3, 7 [R].

\# ARTHRORHAPHIS AERUGinOSA R. Sant. \& Tønsberg - 8: $60^{\circ} 12 ’ 51^{\prime \prime} \mathrm{N}, 29^{\circ} 36^{\prime} 24^{\prime \prime} \mathrm{E}$, pine forest with Calluna vulgaris, Vaccinium myrtillus, and mosses, on squamules of Cladonia sp. on soil, 06.06.2010, leg. DH, EK \& IS (LECB s. n.), 60²'47.6” $\mathrm{N}, 29^{\circ} 36^{\prime} 00.7^{\prime \prime} \mathrm{E}$, swampy pine forest with Ledum palustre, on squamules of Cladonia sp. on wood, 06.05.2016, leg. EK \& IS (LECB s. n.); [R]. New to SPb, previously known from WLR (Stepanchikova et al., 2019).
! Arthrorhaphis citrinella (Ach.) Poelt 8: $60^{\circ} 11^{\prime} 58.3^{\prime \prime} \mathrm{N}, 29^{\circ} 34^{\prime} 08.7$ " E and $60^{\circ} 11^{\prime} 56.4^{\prime \prime} \mathrm{N}, 29^{\circ} 34^{\prime} \mathrm{O} 6.3^{\prime \prime} \mathrm{E}$, pine forest on sandy slope, on soil, 01.05.2016, leg. DH \& IS (Red..., 2018; LECB s. n.) [R].

AsPicilia CINEREA (L.) Körb. - on granite; $1-3,8$, 9 [R]; 21.

Athallia Cerinella (Nyl.) Arup et al. - on bark of Abies sibirica; 9 (Stepanchikova et al., 2014) $\left[R_{1}\right]$.

AtHALlia CERINELloides (Erichsen) Arup et al. - on bark of Tilia sp., on concrete; 8, 9 [R].

Athallia holocarpa (Hoffm.) Arup et al. - on concrete and granite; $2,3,8,9,11,13,14$, 16 [R]; 21.

Athallia PYRACEA (Ach.) Arup et al. - on bark of deciduous trees, rarely on wood; 1-9 [R]; 29, 33.

\# Athelia ARAchnoidea (Berk.) Jülich - on algae and crustose lichens on bark of various trees; 1-4, 6-9 [O].

BACIDIA ARCEUTINA (Ach.) Arnold - on bark of Alnus glutinosa, Populus tremula, Salix spp., Sorbus aucuparia; 2-4, 9 [R].

$\dagger$ Bacidia bagliettoana (A. Massal. \& De Not.) Jatta - on wood; 24 (Elenkin \& Beketov, 1919 , as B. muscorum). No specimens found, but the species is known in other localities in Karelian Isthmus including $\mathrm{SPb}$ (Stepanchikova et al., 2013, 2017b).

$!^{*} \dagger$ BACIDIA FRAXINEA Lönnr. - on bark of Populus tremula; 21, 23, leg. AE, 1900, 1903 (LE L-12530, L-12531, L-12532, L-12644, L-12647, UPS s. n.).

BACIDIA LAUROCERASI (Delise ex Duby) Zahlbr. - 1: on bark of Populus tremula (Stepanchikova et al., 2008) [ $\left.\mathrm{R}_{1}\right]$; 34: on bark of Picea abies (Stepanchikova et al., 2014).

$!^{*} \dagger$ BACIDIA POLYCHROA (Th. Fr.) Körb. - on bark of Populus tremula; 21, 23 (Elenkin, 1904; LE).

!* Bacidia Rubella (Hoffm.) A. Massal. - on bark of Populus tremula, Salix $\times$ fragilis, Ulmus sp.; 3, 9 [R]; 23, 32.

BACIDINA BRANDII (Coppins \& van den Boom) M. Hauck \& V. Wirth - on bark of Alnus glutinosa, wood of Picea abies, fruit bodies of polypores; 2-4 [R].

BACIDiNa CHLOROTICUla (Nyl.) Vězda \& Poelt - on bark of Alnus incana, Betula sp., Populus spp., Salix spp., Vaccinium myrtillus, on granite, iron, mosses, fruit bodies of polypores; 1, 3, 5, 8, 9 [R].

BACIDINA EGENULA (Nyl.) Vězda - on concrete and mosses; 1-4, 8 [R]. 
BACIDINA INUNdATA (Fr.) Vězda - on granite, iron; $3,8,13[R]$.

BACIDINA NEOSQUAMUlosa (Aptroot \& Herk) S. Ekman - on bark of Alnus glutinosa, Populus alba, Salix sp., Ulmus sp.; 3-6 [R].

BACIDINA PHACODES (Körb.) Vězda - 9: 60¹1'49”N, $29^{\circ} 32^{\prime} 43^{\prime \prime} \mathrm{E}$, pine forest with old birches and dog rose on sandy slope, on bark of Betula sp., 16.10.2005, leg. DH, LK \& IS, det. J. V. Gerasimova (LECB s. n.) $\left[\mathrm{R}_{1}\right]$.

BaCidina SUlPhURella (Samp.) M. Hauck \& V. Wirth - on bark of Salix $\times$ fragilis and Vaccinium myrtillus; 3 [R].

BAEOMYCES CARNEUs Flörke - on soil, granite; 8 [R].

BAEOMYCES RUFUs (Huds.) Rebent. - on sandy soil and granites; 6, 8 [R].

Biatora Albohyalina (Nyl.) Bagl. \& Carestia - on bark of Alnus incana, Sorbus aucuparia; 9 (Stepanchikova et al., 2014) [ $\left.\mathrm{R}_{1}\right] ; 34$ (Stepanchikova et al., 2014).

BIATORA BECKHAUSII (Körb.) Tuck. - on bark of Populus tremula; 9 (Stepanchikova et al., 2014) $\left[R_{1}\right]$.

BiATORA EFFLOREscENs (Hedl.) Räsänen - on bark of deciduous trees, on wood; 1-9 [O].

Biatora GLOBUlOSA (Flörke) Fr. - on bark of Alnus incana, Populus alba, Quercus robur, Salix alba; 5, 8, 9 [R].

Biatora HELVOLA Körb. ex Hellb. - on bark of deciduous trees and Picea abies; 1, 3, 7-9, 13 [R]; 25, 34.

BiATORA OCELLIFORMis (Nyl.) Arnold - on bark of Acer platanoides, Alnus incana, Betula sp., Padus avium, Salix sp., Sorbus aucuparia; 1, 7-9 [R]; 34.

Biatora sphaeroidiza (Vain.) Printzen \& Holien - on bark of Acer platanoides and Quercus robur, 8 [R].

$\dagger$ Biatora VERnalis (L.) Fr. - on wood; 24 (Elenkin $\&$ Beketov, 1919). No specimens found, but the species is known in other localities in Karelian Isthmus (H, LE, TUR, UPS).

Bilimbia MicRocarpa (Th. Fr.) Th. Fr. - on mosses and mossy bark of Populus balsamifera and Salix sp.; 1, 9 [R].

Bilimbia sabuletorum (Schreb.) Arnold - on mosses and mossy wood, granite and concrete; 8,9 [R]; 24.

BRIANARIA SYLVICOLA (Flot. ex Körb.) S. Ekman \& M. Svensson - on granite and iron; 1, 8 [R].

$\dagger$ BRYOBILIMBIA HYPNORUM (Lib.) Fryday et al. - on wood; 24 (Elenkin \& Beketov, 1919, as Biatora fusca; no specimens found). The species is known from several historical localities in LR (H, TUR-V), the only recent record is from ELR (Kuznetsova et al., 2007).

Bryoria CAPILlaris (Ach.) Brodo \& D. Hawksw. on bark of conifers, Alnus glutinosa, Betula sp., Populus balsamifera; 9, $14\left[\mathrm{R}_{1}\right] ; 20,21$, 27, 29, 33, 34, 38.

! Bryoria furcellata (Fr.) Brodo \& D. Hawksw. - on bark of Abies sibirica, Pinus sylvestris, and Quercus robur, 9, $10\left[\mathrm{R}_{1}\right] ; 20$.

BRYORIA FUSCESCENS (Gyeln.) Brodo \& D. Hawksw. - on bark and wood; 1-11, 14, 16 [O]; 20, 21, 24, 27, 33, 38.

$\dagger$ BRYORIA NADVORNIKIANA (Gyeln.) Brodo \& D. Hawksw. - on bark of deciduous tree and Pinus sylvestris; 21: 1900, leg. AE (LE s. n., sub Bryoria chalybeiformis (L.) Brodo \& D. Hawksw.); 33, 38 (Malysheva, 1999, 2005). The only available specimen dates back to 1900; the presence of this species in the study area nowadays is doubtful.

! BRYORIA SIMPLICIOR (Vain.) Brodo \& D. Hawksw. - on bark of Betula sp.; 11 (Kataeva, 2002, 2004; Red..., 2018; LE L-10640). The record from 10 (Malysheva et al., 1995) is dubious (Red..., 2018).

BuEllia DisciFormis (Fr.) Mudd - on bark of deciduous trees; $1,7,9,13,16[\mathrm{R}] ; 21,24$, 33, 34, 38.

Buellia ERUBEscens Arnold - on bark of Alnus glutinosa, Padus avium, Populus tremula, Sorbus aucuparia; 1, 6, 7, 9 [R]; 34, 38.

BuEllia GRISEOVIRENS (Turner $\&$ Borrer ex Sm.) Almb. - on bark and wood of deciduous and coniferous trees; 1-4, 6-9 [O]; 34, 37, 38.

BuEllia sCHAERERI De Not. - 3: 6004'29.7”N, $29^{\circ} 57^{\prime} 21.0^{\prime} \mathrm{E}$, seashore black alder forest with bird cherry and rowan undergrowth, on bark of Alnus glutinosa, 28.04.2018, leg. DH \& IS (H s. n.) [ $\left.\mathrm{R}_{1}\right] ; 34$ (Stepanchikova et al., 2014).

! CALICIUM CORYNELlum (Ach.) Ach. - 8: 60¹3'09”N, $29^{\circ} 37^{\prime} 00$ " E, moderately disturbed pine forest with mosses, on granite, 06.06.2010, leg. DH, EK \& IS (Red..., 2018) [R $]$.

Calicium glaudellum Ach. - on bark of Tilia sp. and wood of Pinus sylvestris; 1, 8 [R]; 34.

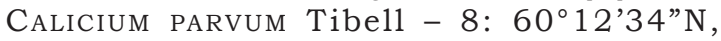
$29^{\circ} 36^{\prime} 35^{\prime \prime} \mathrm{E}$, pine forest with horsetails and Sphagnum spp., with birches, spruces, and willows, on bark of Pinus sylvestris, 06.06.2010, leg. DH, EK \& IS (LECB s. n.) $\left[\mathrm{R}_{1}\right]$. 
Calicium PINASTRI Tibell - on bark of Pinus sylvestris; $6,8[R]$.

CAlicium trabinellum (Ach.) Ach. - on wood of Pinus sylvestris; 6, 8 [R].

! Calicium ViRide Pers. - on bark of Betula sp., Picea abies, Quercus robur, wood; 1, 3, 5 [R]; 34.

Caloplaca albolutescens (Nyl.) H. Olivier - on concrete; 9 (Stepanchikova et al., 2014) [ $\left.R_{1}\right]$.

Caloplaca cerina (Hedw.) Th. Fr. - on bark of Populus spp. and Salix sp.; 1, 2, 4, 8, 9, 11 [R]; 24, 29, 33.

Caloplaca Chlorina (Flot.) H. Olivier - granite and concrete; 2, 5 [R].

Caloplaca lucifuga G. Thor - 5: 6005'24.3”N, $29^{\circ} 55^{\prime} 19.4$ "E, oak stand with birch, on bark of very old Quercus robur near seashore, 10.06.2018, leg. EK \& IS (H s. n.) [R R $_{1}$. New to European Russia, the nearest known localities are in the Russian Caucasus (Vondrák et al., 2017). Distribution in Fennoscandia and Baltic countries: Norway, Sweden, Finland (Nordin et al., 2011), Estonia (Randlane et al., 2019), Latvia (Ābolina et al., 2015), Lithuania (Motiejūnaite, 2017). The species is characterized by corticolous endophloedic thallus, maculiform yellowish grey to dark yellow scattered soralia, presence of parietin and fallacinal, and preference to the bark of very old oaks and humid conditions (Thor, 1988).

Candelariella aurella (Hoffm.) Zahlbr. - on granite and concrete, on bark of Salix sp.; $1-5,8-10,13,14,16$ [R].

Candelariella efflorescens R. C. Harris \& W. R. Buck - on bark of deciduous trees; 1, 2, 4-6, 8, 9, 16 [R]; 18, 33.

CANDElariella lutella (Vain.) Räsänen - on bark of Populus tremula and Salix sp.; 2 [R].

Candelariella vitellina (Hoffm.) Müll. Arg. - on granite, concrete, bark of deciduous trees, wood of Pinus sylvestris; 1-6, 8, 9, 13, 14 [R].

CANDElariella Xanthostigma (Ach.) Lettau - on bark of Populus alba, Quercus robur, Salix spp., Tilia sp.; 1, 3-5, 8, 16 [R].

CAtillaria Nigroclavata (Nyl.) Schuler - on bark of deciduous trees; 1-3, 5, 6, 8, 9 [R].

$\dagger$ Catinaria atropurpurea (Schaer.) Vězda \& Poelt - on bark of Picea abies; 23 (Elenkin, Beketov, 1919). No specimens found, but the species is known from other localities in $\mathrm{SPb}$.

\# Cercidospora epipolytropa (Mudd) Arnold 3: $60^{\circ} 03^{\prime} 47.3^{\prime \prime} \mathrm{N}, 29^{\circ} 57^{\prime} 28.9^{\prime \prime} \mathrm{E}$, boulders on the seashore, on thallus of Lecanora polytropa on granite, 29.04.2018, leg. DH \& IS (BILAS) $\left[\mathrm{R}_{1}\right]$. New to $\mathrm{SPb}$, previously known from WLR (Himelbrant et al., 2013; Stepanchikova et al., 2013).

!† Cetraria ACUleata (Schreb.) Fr. - on soil; 31, 33 (Lemberg, 1935; Fagerström, 1945).

CETRARIA ERICETORUM Opiz subsp. ERICETORUM 8: $60^{\circ} 11^{\prime} 56.4^{\prime \prime} \mathrm{N}, 29^{\circ} 34^{\prime} 06.3^{\prime \prime} \mathrm{E}$, pine forest on slope, on soil, 01.05.2016, leg. DH \& IS (LECB s. n.) [R] ; 17, 21, 33, 37.

CETRARIA ISLANDICA (L.) Ach. subsp. ISLANDICA - on soil, sometimes on bark and wood of Pinus sylvestris; 6-9, 11, 14 [R]; 17, 20, 21, 23, $28,33,35,37,38$. Once (7) a sorediate form called "Cetraria islandica f. sorediata (Schaer.) Arnold" was recorded.

CETRARIA SEPINCOLA (Ehrh.) Ach. - on bark and wood, rarely on stones; 1-11, 13, 14, 16 [O]; 17, 21, 24, 29, 33, 37.

!† Cetrariella DELisei (Bory ex Schaer.) Kärnefelt $\&$ A. Thell - on soil; 35 (Elenkin, 1906, as Cetraria hiascens (Fr.) Th. Fr.). The nearest actual locality is in the vicinity of Lake Schuch'e near Komarovo (Stepanchikova et al., 2017b).

!* Chaenotheca BRachypoda (Ach.) Tibell - on bark of Betula sp. and Salix alba, wood of Alnus glutinosa, fruit bodies of polypores; 2, 5, 7-9 [R].

Chaenotheca Brunneola (Ach.) Müll. Arg. - on wood of Pinus sylvestris; 11 (Kataeva, 2002, 2004); 34 (Stepanchikova et al., 2014).

Chaenotheca chrysocephala (Turner ex Ach.) Th. Fr. - on bark of Alnus glutinosa, Picea abies, Quercus robur, Tilia sp., on wood; 1, $2,7,8,13$ [R].

Chaenotheca ferruginea (Turner ex Sm.) Mig. - on bark and wood of conifers, on bark of Alnus glutinosa, Betula sp., Quercus robur, $1-9,11,13,14,16[\mathrm{O}] ; 34$.

Chaenotheca Furfuracea (L.) Tibell - on bark of Alnus spp., Betula sp., Picea abies, wood, soil under upturned roots, fruit bodies of polypores; 1-4, 7 [R].

!*CHAenotheca Hispidula (Ach.) Zahlbr. - on bark of Alnus glutinosa, Quercus robur, 1, 2, 5 [R].

!§CHAENotheCA PHAEOCEPHALA (Turner) Th. Fr. - on bark of Quercus robur, 1, 5 [R].

!* Chaenotheca stemonea (Ach.) Müll. Arg. - on bark of Picea abies, on wood; 2, 3, 7, 8 [R]; 24.

!§† ChaEnotheca SUBRoscida (Eitner) Zahlbr. - on bark of Picea abies; 34 (Stepanchikova et al., 2014; Red..., 2018). 
Chaenotheca trichialis (Ach.) Th. Fr. - on bark and wood; 1, 3-5, 7-9, 11 [O]; 18, 34.

CHAENOTHECA XYLOXENA Nádv. - 3: 6004'14.4”N, $29^{\circ} 57^{\prime} 00.3^{\prime \prime} \mathrm{E}$, old oak stump near the path, on wood of Quercus robur, 20.04.2018, leg. EK \& IS (H s. n.) [ $\left.\mathrm{R}_{1}\right]$. New to SPb, previously known from ELR and WLR (Kuznetsova et al., 2007; Stepanchikova et al., 2013).

+ Chaenothecopsis debilis (Sm.) Tibell - 8: $60^{\circ} 12^{\prime} 28^{\prime \prime} \mathrm{N}, 29^{\circ} 34^{\prime} 11^{\prime \prime} \mathrm{E}$, birch forest with mosses and grasses, on wood of Pinus sylvestris, 18.07.2010, leg. EK \& IS (LECB s. n.) $\left[R_{1}\right]$. New to $\mathrm{SPb}$, previously known from ELR and WLR (Kuznetsova et al., 2007; Himelbrant et al., 2018).

*\# Chaenothecopsis Epithallina Tibell - on thalli of Chaenotheca trichialis on wood and bark of conifers; 7, 8 [R].

*+ ChAENothecopsis NIGRA Tibell - 8: 60² 12 '28”N, $29^{\circ} 34^{\prime} 11^{\prime \prime} \mathrm{E}$, birch forest with mosses and grasses, on bark of Pinus sylvestris, 18.07.2010, leg. EK \& IS (LECB s. n.) [ $\left.R_{1}\right]$.

(\#) Chaenothecopsis pusilla (Ach.) A. F. W. Schmidt - on bark of Pinus sylvestris and Quercus robur, on wood, upturned roots, and on thallus of Hypocenomyce scalaris; $1,3,5,7,8[R] ; 34$.

*\#) Chaenothecopsis pusiola (Ach.) Vain. - 3: $60^{\circ} 04^{\prime} 08.2^{\prime \prime} \mathrm{N}, 29^{\circ} 57^{\prime} 18.2^{\prime \prime} \mathrm{E}$, mossy spruce forest with pines and birches, on thallus of Chaenotheca trichialis on fallen trunk of Pinus sylvestris, 20.04.2018, leg. EK \& IS (H s. n.) $\left[\mathrm{R}_{1}\right]$.

+ ChaEnothecopsis savonica (Räsänen) Tibell - on wood and algae on wood; 1, 2, 9 [R].

$! \S^{+} \dagger$ Chaenothecopsis viridialba (Kremp.) A. F. W. Schmidt - on bark of Picea abies; 34 (Stepanchikova et al., 2014).

CHRYSOTHRIX CANDELARIS (L.) J. R. Laundon - on bark of Alnus glutinosa and Pinus sylvestris; $1,11\left[R_{1}\right]$.

Circinaria CAEsiocinerea (Nyl. ex Malbr.) A. Nordin et al. - on granite; 1, 2, 6 [R].

Circinaria Contorta (Hoffm.) A. Nordin et al. - on concrete; 1,9 [R].

Cladonia amaurocraea (Flörke) Schaer. - 8: $60^{\circ} 12^{\prime} 51^{\prime \prime} \mathrm{N}, 29^{\circ} 36^{\prime} 24^{\prime \prime} \mathrm{E}$, pine forest with Calluna vulgaris, Vaccinium myrtillus, and mosses, on wood of conifers, 06.06.2010, leg. DH, EK \& IS (LECB s. n.) [R] ]; 17: on soil (Elenkin \& Beketov, 1919).

Cladonia ARBuscula (Wallr.) Flot. subsp. arbusCULA - on soil, rarely on bark and wood of conifers; 1, 2, 6-9, 11, 12, 14 [R]; 17, 20, $21,23,24,33,35,37$.

Cladonia BACILliformis (Nyl.) Sarnth. - on bark and wood of conifers, on bark of Betula sp., on soil; 6-9, 12, 16 [R].

! Cladonia Bellidiflora (Ach.) Schaer. - on sandy soil and bark of Betula sp.; 1, 8 [R].

Cladonia borealis S. Stenroos - on soil; 8 [R].

Cladonia botrytes (K. G. Hagen) Willd. - on bark and wood of Pinus sylvestris, on bark of Betula sp.; 1, 2, 6-9, 12-14, 16 [R]; 17, 21, 33, 37, 38.

Cladonia CAEspiticia (Pers.) Flörke - on bark of Alnus glutinosa, Betula sp., on wood; 2, 3, $9[R]$.

Cladonia Cariosa (Ach.) Spreng. - on soil; 1, 2 [R]; 17, 24.

Cladonia Carneola (Fr.) Fr. - on soil; 6 [R $]$.

Cladonia CEnotea (Ach.) Schaer. - on soil, bark and wood; 1-3, 6-9, 11-16 [O]; 21, 24, 33.

Cladonia Chlorophaea (Flörke ex Sommerf.) Spreng. s. str. - on soil, wood of conifers, bark of Alnus glutinosa, Betula sp., Populus alba, Salix $\times$ fragilis, and Sorbus aucuparia; 2-6 [R]. Thalli contain fumarprotocetraric acid.

Cladonia coniocraea (Flörke) Spreng. - on bark, wood, soil, and fruit bodies of polypores; $1-9,11-14,16[\mathrm{~F}]$.

Cladonia cornuta (L.) Hoffm. subsp. cornuta - on soil, wood of conifers, bark of Alnus incana, Betula sp., Pinus sylvestris, Sorbus aucuparia; 1-3, 6-9, 11-14, 16 [R]; 20, 21, 24, 33, 37, 38.

Cladonia CRISPATA (Ach.) Flot. (var. CRISPATA and var. CETRARIIFORMIS (Delise) Vain.) - on soil, wood of Pinus sylvestris, bark of Betula sp., Pinus sylvestris; 1, 6-9, 11, 12, 16 [R]; 17, 24, 33, 37, 38.

Cladonia DEFormis (L.) Hoffm. - on soil and wood of conifers, bark of Alnus incana, Betula sp., Pinus sylvestris; 6-9, 11, 12, 14, 16 [R]; 20, 21, 24, 27, 30, 33, 37.

Cladonia digitata (L.) Hoffm. - on soil and wood, bark of Alnus spp., Betula sp., Picea abies, Pinus sylvestris; 1, 3, 5-9, 11, 12, 14, 16 [R]; 21, 24, 27, 34.

Cladonia fimbriata (L.) Fr. - on bark, wood and soil; 1-4, 6-10, 12-14, 16 [O]; 21, 24, 27-29, 33, 37, 38.

Cladonia floerkeana (Fr.) Flörke - on bark of Pinus sylvestris, wood and soil; 7-9, 16 [R]; 24, 33, 37. 
Cladonia furcata (Huds.) Schrad. - on soil; 1, 2, 8, 9, 11-14, 16 [R]; 20, 24, 33, 37, 38.

ClaDONIA GRACILIS (L.) Willd. (subsp. GRACILIS and subsp. TURBINATA (Ach.) Ahti) - on soil, bark of Betula sp., bark and wood of conifers; 2, 6-9, $11,12,14,16$ [R]; 17, 24, 29, 33, 37, 38.

Cladonia grayi G. Merr. ex Sandst. - on soil, wood, bark of Betula sp., Picea abies; 3, 6, $8,11,12,16[R] ; 21$. Thalli contain fumarprotocetraric and grayanic acids.

Cladonia macilenta Hoffm. - on soil, bark and wood; 1, 5-9, 11, 12, 16 [R].

Cladonia Macrophylla (Schaer.) Stenh. - 8: $60^{\circ} 13^{\prime} 09^{\prime \prime} \mathrm{N}, 29^{\circ} 37^{\prime} \mathrm{O} 0^{\prime \prime} \mathrm{E}$, disturbed pine forest with mosses, on primary soil, 06.06.2010, leg. DH, EK \& IS (LECB s. n.) [ $\left.\mathrm{R}_{1}\right]$. One more record of this species is erroneously cited by Malysheva (2003): the original material was collected outside of limits of $\mathrm{SPb}$.

Cladonia mitis Sandst. - on soil, rarely on wood of conifers; 2, 6, 8 [R]; 20, 33, 38.

!* Cladonia norvegica Tønsberg \& Holien - 7: $60^{\circ} 11^{\prime} 03^{\prime \prime} \mathrm{N}, 29^{\circ} 46^{\prime} 14^{\prime \prime} \mathrm{E}$, spruce forest with birch, on bark of Betula sp., 30.09.2006, leg. DH, EK \& IS (LECB s. n.) (Red..., 2018) [R ${ }_{1}$.

Cladonia novochlorophaea (Sipman) Brodo \& Ahti - on bark of Betula sp. and on sandy soil; 6 [R]. Thalli contain sekikaic and homosekikaic acids.

ClADONIA OCHROCHLORA Flörke - on bark of Alnus glutinosa, Betula sp., and Quercus robur, on wood of Pinus sylvestris; 1, 3, 7, 8, 11 [R]; 33.

Cladonia PHYLLOPHORA Hoffm. - on soil and bark of Betula sp.; 1, 2, 6-9 [R]; 20, 33, 37.

Cladonia PleUROTA (Flörke) Schaer. - on soil, bark of Betula sp., Sorbus aucuparia; 6-9, 14 [R].

Cladonia pyxidata (L.) Hoffm. - on soil; 7, 8, 14 [R]; 24, 33, 37.

Cladonia Rangiferina (L.) F. H. Wigg. - on soil, rarely on bark and wood of conifers and Betula sp.; 2, 6-9, 11, 14 [R]; 17, 20, 21, 23, 24, 33, 35, 37.

CLADONIA REI Schaer. - on soil, rarely on wood and bark of Pinus sylvestris; 1, 2, 6, 8, 9, 16 [R].

! Cladonia squamosa Hoffm. - on soil; 6, 8 [R].

! Cladonia stellaris (Opiz) Pouzar \& Vězda - on soil; 14; 17, 20, 26, 33, 37.

Cladonia stygia (Fr.) Ruoss - on soil; 6, 9 [R].

Cladonia subulata (L.) F. H. Wigg. - on soil; 6 , 8 , $12,13,14,16[\mathrm{R}] ; 37$.

Cladonia sulphurina (Michx.) Fr. - on soil, bark and wood Pinus sylvestris, bark of Betula sp.; 6-9, $11[\mathrm{R}]$.
Cladonia turgida Hoffm. - 8: 60¹3'08.0”N, $29^{\circ} 36^{\prime} 38.5^{\prime \prime} \mathrm{E}$, subway of a sandy road, on sandy soil, 06.06.2010, DH, EK \& IS (LECB s. n.) [R] $] 17$ (Elenkin \& Beketov, 1919).

Cladonia uncialis (L.) F. H. Wigg. (subsp. uncialis and subsp. BIUNCIALIS (Hoffm.) M. Choisy) on soil, rarely on bark of conifers; 7-9, 11, 14 [R]; 33, 37.

Cladonia verticillata (Hoffm.) Schaer. - on soil, once on bark of Pinus sylvestris; 2, 6-9 [R]; $17,33$.

$\dagger$ Cliostomum GRiffithiI (Sm.) Coppins - on bark of Picea abies; 23 (Elenkin \& Beketov, 1919, as Biatorina tricolor (With.) Stein.). This locality is the only one known in $\mathrm{SPb}$; the species currently occurs in different parts of LR.

\# ClypeococCum HYPoCENomycis D. Hawksw. - on thalli of Hypocenomyce scalaris on bark and wood of conifers; 2-5, 7-9 [R].

Coenogonium Pineti (Ach.) Lücking \& Lumbsch - on bark, wood, soil, plant debris, mosses, and fruit bodies of polypores; 1-9, $11[\mathrm{~F}]$.

Dibaeis BAEOMYCEs (L. f.) Rambold \& Hertel - 8: $60^{\circ} 11^{\prime} 56.4^{\prime \prime} \mathrm{N}, 29^{\circ} 34^{\prime} \mathrm{O} 6.3$ " $\mathrm{E}$, pine forest on slope, on sandy soil, 01.05.2016, leg. DH \& IS (LECB s. n.) [ $\left.R_{1}\right]$.

! Dictyocatenulata alba Finley \& E. F. Morris on bark of Tilia sp.; 1 (Stepanchikova et al., 2010; Red..., 2018) [R $\mathrm{R}_{1}$.

Diploschistes scRuposus (Schreb.) Norman - 8: $60^{\circ} 13^{\prime} 09^{\prime \prime} \mathrm{N}, 29^{\circ} 37^{\prime} 00^{\prime \prime} \mathrm{E}$, partly disturbed pine forest with mosses, on granite, 06.06.2010, leg. DH, EK \& IS (LECB s. n.) $\left[\mathrm{R}_{1}\right]$.

Enchylium tenax (Sw.) Gray - 2: 6001'18.3”N, $29^{\circ} 58^{\prime} 41.4$ "E, anthropogenic wasteland, on soil, 27.05.2018, leg. DH, EK \& IS (LECB s. n.) $\left[R_{1}\right]$. New to $S P b$, previously known from WLR (Alexeeva \& Himelbrant, 2007).

\# Endococcus fusiger Th. Fr. et Almq. - 8: $60^{\circ} 13^{\prime} 09^{\prime \prime} \mathrm{N}, 29^{\circ} 37^{\prime} 00^{\prime \prime} \mathrm{E}$, moderately disturbed pine forest with mosses, on thallus of Rhizocarpon cf. polycarpum on granite, 06.06.2010, leg. DH, EK \& IS (BILAS) [R ${ }_{1}$. New to $\mathrm{SPb}$, previously known from WLR (Himelbrant et al., 2014).

\# Endococcus verrucosus Hafellner - 2: $60^{\circ} 00^{\prime} 36.6^{\prime \prime} \mathrm{N}, 29^{\circ} 57^{\prime} 50.8^{\prime \prime} \mathrm{E}$, young aspen stand with dog rose on old boulder pier, on thallus of Circinaria caesiocinerea on granite boulder, 06.05.2018, leg. DH, EK $\&$ IS (BILAS) [R1]. New to Northwestern European Russia. The nearest locality in 
European Russia is known in Tver' Region (Zhurbenko, Notov, 2015). Distribution in Fennoscandia and Baltic countries: Norway (Nordin et al., 2011), not recorded in Baltic countries. Characterized by granulate/verruculose ascospores. Our specimen had wider range of the ascospore size than in the protologue (Hafellner, 1994). Ascospore size and other characters coincided with these provided by Zhurbenko and Notov (2015), but the ascomata were almost fully sunken in the host thallus, forming in places small, gall-like protrusions.

EOPYRENUlA LEUCOPLACA (Wallr.) R. C. Harris - 4: $60^{\circ} 05^{\prime} 14.9^{\prime \prime} \mathrm{N}, 29^{\circ} 57^{\prime} 00.1$ 'E, black alder, grey alder, and poplar trees on the bank of the channel, on bark of Populus sp., 05.05.2018, leg. DH, EK \& IS (LECB s. n.) $\left[\mathrm{R}_{1}\right]$.

EVERNIA MESOMORPHA Nyl. - on bark of conifers, Alnus spp., Betula sp., Tilia sp., on wood; 1, 3, 7-9, 11 [R]; 18, 20, 24.

EVERNIA PRUNASTRI (L.) Ach. - on bark and wood; $1-11,13,14,16$ [O]; 17, 18, 20, 21, 23, 24, 29, 33, 34, 37, 38.

Fellhanera subTilis (Vězda) Diederich \& Sérus. - on bark of Alnus incana, Corylus avellana, Calluna vulgaris, Picea abies, Rosa sp., Sorbus aucuparia, Vaccinium myrtillus; 3, 6-8 [R].

FlaVoplaCA CITRINA (Hoffm.) Arup et al. - on concrete; 4, 9 [R].

FlaVoplaCA DiCHROA (Arup) Arup et al. - on concrete; 9 (Vondrák et al., 2010; LE L-7398) $\left[R_{1}\right]$.

Flavoplaca FlaVocitrina (Nyl.) Arup et al. - on concrete; 9 (Himelbrant et al., 2015) $\left[R_{1}\right]$.

FRUTIDELla FURFURACEA (Anzi) M. Westb. \& M. Svensson - 8: 60¹2’34”N, 29³6’35”E, pine forest with horsetails and Sphagnum spp., with birches, spruces and willows, on bark of Betula sp., 06.06.2010, leg. DH, EK \& IS (LECB s. n.) [R $\mathrm{R}_{1}$.

Fuscidea ARBoRICOLA Coppins \& Tønsberg - on bark of Alnus spp., Corylus avellana, Padus avium, Pinus sylvestris, Populus tremula, Salix sp., Sorbus aucuparia, Ulmus sp.; 2, 3, 7-9, $11[\mathrm{R}]$.

Fuscidea PUSILla Tønsberg - on bark and wood; $1-9[\mathrm{C}]$.

GRAPHIS SCRIPTA (L.) Ach. - on bark of deciduous trees, once on bark of Picea abies; 1-3, 6-9, $11[\mathrm{O}] ; 18,23,34$.
Gyalecta fagicola (Hepp ex Arnold) Kremp. - on bark of deciduous trees; 2-5, 8, 9 [R]; 29, 34.

GyaleCtA NIGRICANS Vain. - 2: 6000'35.3”N, $29^{\circ} 58^{\prime} 35.6$ " E, deciduous swampy forest with spruces, on bark of Alnus glutinosa, 20.05.2018, leg. DH, EK \& IS (LECB s. n.) $\left[R_{1}\right]$. New to European Russia. This species was previously known only from a few regions of Western Siberia (Gagarina, 2017). Characterized by black (rarely brown-black) apothecia and transversely septate ascospores with 5-8 septa. Gyalecta nigricans is rather similar to G. truncigena (Ach.) Hepp which sometimes also has blackish apothecia (especially old ones), but the apothecia of G. truncigena are larger $(0.2-0.7 \mathrm{~mm}$ diam. - G. truncigena; 0.1-0.3 mm diam. - G. nigricans). In addition, $G$. nigricans differs from G. truncigena by the type of spores and their arrangement in the ascus: G. nigricans has transversely septate ascospores located in the ascus in two rows, while ascospores of G. truncigena are sparingly muriform and located in one row.

GyaloleChia FLAVORUBEscens (Huds.) Søchting et al. - 8: $60^{\circ} 11^{\prime} 49.5^{\prime \prime} \mathrm{N}, 2^{\circ} 33^{\prime} 35.2^{\prime \prime} \mathrm{E}$, poplar alley on the top of slope, on bark of Populus alba, 01.05.2016, leg. DH \& IS (LECB s. n.) $\left[\mathrm{R}_{1}\right] ; 27,37$.

\# Heterocephalacria physciacearum (Diederich) Millanes \& Wedin - on thalli of Physcia spp. on bark of deciduous trees; 2, 3 [R].

HYPOCENOMYCE SCALARIS (Ach.) M. Choisy - on bark and wood of conifers, more rarely of deciduous trees; $1-11,13,14,16[\mathrm{~F}] ; 17$, 20, 23, 33, 34, 38.

HYPOGYMNIA FARINACEA Zopf - on bark of Alnus glutinosa, Betula sp., Fraxinus excelsior, Pinus sylvestris, Salix sp.; 1, 5-7 [R].

HYPOGYMNIA PHYSODES (L.) Nyl. - on bark and wood, rarely on soil, stones and mosses; $1-11,13,14,16$ [VC] ; 17, 18, 20-22, 24, 33, 35, 37, 38.

HyPogymnia tubulosa (Schaer.) Hav. - on bark and wood, rarely on soil and granite; 1-11, 14, $16[\mathrm{~F}] ; 22,33,35,38$.

$* \dagger$ ICMADOPHILA ERICETORUM (L.) Zahlbr. - on wood; 21, 24, 27 (Elenkin, 1904; Elenkin \& Beketov, 1919; Malysheva, 2003).

\# Illosporiopsis christianseniI (B. L. Brady \& D. Hawksw.) D. Hawksw. - on thalli of Physcia spp. on bark of deciduous trees; 1, 4-6, 9 [R]. 
Imshaugia Aleurites (Ach.) S. L. F. Meyer - on bark and wood of Pinus sylvestris; 6, 7, 9 [R]; 17, 24, 29, 33.

!§ Inoderma Byssaceum (Weigel) Gray - 5: $60^{\circ} 05^{\prime 2} 2.2^{\prime \prime} \mathrm{N}, 2^{\circ} 55^{\prime} 39.8^{\prime \prime E}$, medium-aged oaks on seashore, on bark of Quercus robur, 10.06.2018, leg. EK \& IS (LECB s. n.), $60^{\circ} 05^{\prime} 23.9^{\prime \prime} \mathrm{N}, 2^{\circ} 55^{\prime} 29.7^{\prime \prime} \mathrm{E}$, group of old oaks in the park, on bark of $Q$. robur, 04.06.2018, leg. EK \& IS (LECB s. n.), $60^{\circ} 05^{\prime} 24.3^{\prime \prime} \mathrm{N}, 29^{\circ} 55^{\prime} 19.4$ " E, oak stand with birches, on bark of Q. robur, 10.06.2018, leg. EK \& IS (H); [R].

JAPEWIA SUBAURIFERA Muhr \& Tønsberg - on bark of Alnus glutinosa, Betula sp., Picea abies, Sorbus aucuparia, on bark and wood of Pinus sylvestris; 3, 6-9 [R].

LECANIA CYRTELLA (Ach.) Th. Fr. - on bark of deciduous trees; 1-9, 13 [O]; 33, 38.

LeCANia CYRTELlina (Nyl.) Sandst. - on bark of Acer platanoides, Alnus glutinosa, Padus avium, Populus tremula, Salix spp., Sorbus aucuparia; 1-3, 6, 8, 9 [R]; 34.

LeCANia Dubitans (Nyl.) A. L. Sm. - on bark of Betula sp., Populus spp., Salix sp., and Ulmus sp.; 1, 4, 9, 13 [R]; 24.

LeCANIA FUSCELla (Schaer.) A. Massal. - on bark of Salix $\times$ fragilis and Sorbus aucuparia; 2, $3,13[R]$.

LeCANia NAEGEli (Hepp) Diederich \& van den Boom - on bark of deciduous trees, rarely on wood; 1-9 [O]; 29, 38.

LECANIA SYLVESTRIS (Arnold) Arnold - on concrete and iron; 2, 8, 9 [R].

Lecania turicensis (Hepp) Müll. Arg. - 2: $60^{\circ} 00^{\prime} 41.6^{\prime \prime} \mathrm{N}, 2^{\circ} 57^{\prime} 58.8^{\prime \prime} \mathrm{E}$, basement of a burnt house on a glade, on concrete, 06.05.2018, leg. DH, EK \& IS (H) [R $]$. New to Northwestern European Russia, the nearest known localities in the European Russia are in the Tver' Region (Notov et al., 2011). Distribution in Fennoscandia and Baltic countries: Sweden (Nordin et al., 2011), Estonia (Randlane et al., 2019), Lithuania (Motiejūnaité, 2017). Characterized by densely white pruinose granular to rimose areolate thallus, pruinose apothecia, and 1-septate ascospores (Foucard, 2001; Fletcher et al., 2009).

LECANORA AITEMA (Ach.) Hepp - on bark of Sorbus aucuparia, wood of Pinus sylvestris and Salix sp.; 3, 4 [R]. $\dagger$ Lecanora albella (Pers.) Ach. - on bark of deciduous trees; 33, 34 (Merezhkovsky, 1906; Stepanchikova et al., 2014).

LeCANora Albellula (Nyl.) Th. Fr. - on bark and wood; 1-9 [O]; 17.

LECANORA ALLOPHANA Nyl. - on bark of Abies sibirica, Populus spp., Quercus robur, Sorbus aucuparia, on wood; 2-6, 8-10, 13, 14 [R]; 21, 24, 33.

LECANORA ANOPTA Nyl. - 6: 6007'34.3”N, $29^{\circ} 58^{\prime} 14.1$ 'E, young pine forest with mosses, and Vaccinium myrtillus, on bark of Pinus sylvestris, 19.05.2018, leg. DH, EK (LECB s. n.) $\left[R_{1}\right]$. New to $\mathrm{SPb}$, previously known from ELR and WLR (Kuznetsova et al., 2007; Himelbrant et al., 2018).

LECANORA ARGENTATA (Ach.) Malme - on bark of deciduous trees; $1,4,7,9,10,13,14,16$ [R]; 21, 34.

LECANORA CADUbriae (A. Massal.) Hedl. - on bark and wood of Pinus sylvestris; 6 [R]; 17, 34.

LECANORA CARPINEA (L.) Vain. - on bark of deciduous trees, once on wood of Pinus sylvestris; $1-10,13,14,16[\mathrm{~F}] ; 18,21,24,29,33,34$, $37,38$.

$\dagger$ LeCanora Cateilea (Ach.) A. Massal. - on bark of deciduous tree; 34 (Stepanchikova et al., 2014).

LECANORA CHLAROTERA Nyl. - on bark and wood, rarely on granite; 1-9 [O].

LECANORA CIRCUMBOREALIS Brodo \& Vitik. - on bark of Alnus glutinosa and wood of Pinus sylvestris; 6, 11 [R].

LECANORA CONIZAEOIDES Nyl. ex Cromb. - on bark of Alnus spp., Betula sp., Larix sp., Picea abies, Pinus sylvestris; 1, 3, 8, 9 [R].

LECANORA EXPALLENS Ach. - 5: 6005'24.3"N, $29^{\circ} 55^{\prime} 19.4$ "E, oak stand with birch, on bark of Quercus robur, 10.06.2018, leg. EK \& IS (LECB s. n.) [ $\left.\mathrm{R}_{1}\right]$. Thallus contains arthothelin, zeorin, usnic and thiophanic acids.

LECANORA HYPOPTA (Ach.) Vain. - 8: 60²'45.1”N, $29^{\circ} 35^{\prime} 00.0^{\prime \prime} \mathrm{E}$, pine forest with feather mosses, on bark of Pinus sylvestris, 03.05.2016, leg. DH \& IS (LECB s. n.) [ $\left.\mathrm{R}_{1}\right]$.

LECANORA HYPOPTELLA (Nyl.) Grummann - on bark of Alnus glutinosa, Pinus sylvestris, Sorbus aucuparia, wood of Pinus sylvestris; 3, 4, $6,8[R]$.

LECANORA HYPOPTOIDES (Nyl.) Nyl. - 6: 6008'01.8”N, $29^{\circ} 57^{\prime} 52.4^{\prime \prime E}$, swampy pine forest with mosses, Ledum palustre, and Vaccinium 
myrtillus, on bark of Pinus sylvestris, 19.05.2018, leg. DH \& EK (LECB s. n., sub Lecanora cadubriae) $\left[\mathrm{R}_{1}\right]$.

LECANORA INTRICATA (Ach.) Ach. - on granite; 2, 3, 6, 8, 9 [R].

LECANORA NORVEGICA Tønsberg - on bark of Pinus sylvestris; 8 [R].

LECANORA PHAEOSTIGMA (Körb.) Almb. - on bark of Pinus sylvestris; 7, 9 [R]; 17.

LECANORA POLYTROPA (Ehrh. ex Hoffm.) Rabenh. - on granite; $1-3,6,8[R]$.

LECANORA POPUlicola (DC.) Duby - on bark of Populus spp.; 1, 2, 6, 8, 9 [R]; 29.

LECANORA PULICARIS (Pers.) Ach. - on bark and wood; 1-9, 11, 13, 14, 16 [C]; 21, 33, 34, $37,38$.

LECANORA SALIGNA (Schrad.) Zahlbr. - on wood of Pinus sylvestris; 3, 6 [R].

LECANORA SUBINTRICATA (Nyl.) Th. Fr. - on bark of Betula sp., Pinus sylvestris, Sorbus aucuparia, and wood of Pinus sylvestris; 1, 3, 6, 9 [R]; 38.

LECANORA SYMMicta (Ach.) Ach. - on bark and wood, on fruit bodies of polypores; 1-9, 11, 13, 14, 16 [C]; 21, 24, 29, 33, 37.

LECANORA UMBRINA (Ach.) A. Massal. - on granite, bark of deciduous trees and wood of conifers; 1-9 [R].

LECANORA VARIA (Hoffm.) Ach. - on bark and wood; $1-7,9,11,14,16$ [R]; 18, 20, 21, 37, 38.

LeCidEA ALBOFUSCESCENS Nyl. - on bark of Sorbus aucuparia and Betula sp.; 9 (Stepanchikova et al., 2014) $\left[\mathrm{R}_{1}\right] ; 25$ (Elenkin \& Beketov, 1919).

LECIDEA ERYTHROPHAEA Flörke ex Sommerf. - 8: $60^{\circ} 12^{\prime 2} 29.6 ” \mathrm{~N}, 2^{\circ} 35^{\prime} 45.0^{\prime} \mathrm{E}$, spruce-aspenbirch forest with Vaccinium myrtillus and Sphagnum spp., on bark of Populus tremula, 06.05.2016, leg. EK \& IS (LECB s. n.) [R $]$.

Lecidea fuscoatra (L.) Ach. - on granite; 9 (Stepanchikova et al., 2014) $\left[R_{1}\right]$.

LECIDEA LAPICIDA (Ach.) Ach. (var. LAPICIDA and var. PANTHERINA Ach.) - on granite; 8, 9 [R].

LECIDEA LEPRARIOIDES Tønsberg - 7: 60 $11^{\prime} 17^{\prime \prime} \mathrm{N}$, $29^{\circ} 46^{\prime} 02$ " E, pine forest with Calluna vulgaris and feather mosses, on bark of Pinus sylvestris, 07.05.2017, leg. DH \& IS (LECB s. n.) $\left[\mathrm{R}_{1}\right]$. New to $\mathrm{SPb}$, previously known from ELR and WLR (Kuznetsova et al., 2007, 2016; Himelbrant et al., 2018).

LECIDEA MALMEANa Zahlbr. - 8: 60¹3'09"N, $29^{\circ} 37^{\prime} 00^{\prime} \mathrm{E}$, moderately disturbed pine forest with mosses, on bark of Pinus sylvestris,
06.06.2010, leg. DH, EK \& IS (LECB s. n.) $\left[R_{1}\right]$. New to Russia. Distribution in Fennoscandia and Baltic countries: Sweden (Nordin et al., 2011). This extremely rarely recorded species belongs to " $L$. malmeana complex", in Europe it is known also from Switzerland (Nimis et al., 2018). In well concordance with the protologue (Malme, 1895) and authentic material (Malme, Lichenes Suecici Exsiccati no. 988, H!), our specimen has whitish thin thallus, small black apothecia to $0.3 \mathrm{~mm}$ diam. with persistent margin, dark (blackish) epihymenium and hypothecium, both slightly olivaceous-green in $\mathrm{K}(\mathrm{K}$ - in protologue), distinctly capitate paraphyses $1 \mu \mathrm{m}$ wide with apical part $4 \mu \mathrm{m}$ wide, $8-16$ spores per ascus, ascospores colorless, simple, narrowly ellipsoid, $7 \times 2-2.7 \mu \mathrm{m}$.

LECIDEA NYLANDERI (Anzi) Th. Fr. - on bark and wood of conifers, Betula sp., and Alnus glutinosa; 2-9 [O]; 34.

LeCidea Plebeja Nyl. - 6: 6006'36.4”N, $29^{\circ} 57^{\prime} 37.9^{\prime \prime} \mathrm{E}$, disturbed pine forest on sand of river bank slope, on wood of Pinus sylvestris, 04.06.2018, leg. EK \& IS (LECB s. n.) $\left[\mathrm{R}_{1}\right]$. New to $\mathrm{SPb}$, previously known from ELR and WLR (Kuznetsova et al., 2007; Himelbrant et al., 2018; Stepanchikova et al., 2019).

LECIDEA TURGIDULA Fr. - on bark and wood of conifers; 6-8 [R]; 17, 24.

Lecidella elaeochroma (Ach.) M. Choisy - on bark of deciduous trees; 1-9, 16 [O]; 33.

LECIDELLA EUPHOREA (Flörke) Hertel - on bark of Populus spp., Quercus robur, Sorbus aucuparia, and Ulmus sp.; 1-3, 6, 8-10, 13, 14 [R]; 24, 28.

Lecidella stigmatea (Ach.) Hertel \& Leuckert - on granite and concrete; 1-4, 6, 8, 9 [R].

LEMMOPSIS ARNOLDIANA (Hepp) Zahlbr. - on concrete; 9 (Stepanchikova et al., 2014) $\left[R_{1}\right]$.

LEPRA ALBESCEns (Huds.) Hafellner var. ALBESCENS - on bark of Padus avium, Quercus robur, Sorbus aucuparia, and Tilia sp.; 1, 2, 8, $10[\mathrm{R}]$.

LEPRA AMARA (Ach.) Hafellner - on bark of Alnus spp., Populus tremula, Quercus robur, and Tilia sp., wood of Quercus robur; 1, 3, 5, 8 [R]; 21, 34, 37, 38.

LEPRARIA ELOBATA Tønsberg - on bark, wood, soil, upturned roots, granite, and mosses; $1-9[\mathrm{~F}]$. 
LEPRARIA INCANA (L.) Ach. - on bark, wood, and granite; 1-10, 13, 14, $16[\mathrm{~F}]$.

LEPRARIA JACKII Tønsberg - on bark, wood, soil, plant debris, upturned roots, and mosses; 1-3, 6-9 [O].

LEPRARIA LOBIFICANS Nyl. - on bark, wood, soil, upturned roots, granite, and mosses; 1-3, 5, 7-9 [O].

LEPRARIA NEGLECTA (Nyl.) Lettau - on granite; 2, 8 [R]. Thalli contain alectorialic acid.

$!^{*} \dagger$ LEPTOGIUM SATURninum (Dicks.) Nyl. - 23: 1906, leg. AE (Malysheva, 2003; LE L-11155, L-11156).

LEPTORHAPHIS ATOMARIA (Ach.) Szatala - on bark of Populus spp.; 2-6, 8, 9 [R]; 23.

+ LEPTORHAPHIS EPIDERMIDIS (Ach.) Th. Fr. - on bark of Betula sp.; 6, 8, 9, 13 [R]; 21, 24.

LEPTORHAPHIS LUCIDA Körb. - on bark of Populus balsamifera; 11 (Kataeva, 2002, 2004).

\# Lichenochora obscuroides (Linds.) Triebel \& Rambold - 4: 6005'14.9'N, 2957'00.1'E, deciduous stand on the bank of a channel, on thallus of Phaeophyscia orbicularis on bark of Populus sp., 05.05.2018, leg. DH, EK \& IS (H) $\left[\mathrm{R}_{1}\right]$.

\# Lichenoconium ERodens M. S. Christ. \& D. Hawksw. - 6: 6007'49.9”N, 2957'20.5”E, pine forest with birch, mosses, and Vaccinium myrtillus, on thallus of Hypogymnia physodes on bark of Pinus sylvestris, 19.05.2018, leg. DH, EK \& IS (BILAS) [ $\left.\mathrm{R}_{1}\right]$. New to $\mathrm{SPb}$, previously known from WLR (Stepanchikova et al., 2017a, 2019).

\# Lichenoconium lichenicola (P. Karst.) Petr. \& Syd. - 3: 6003'52.8”N, 2957'07.5”E, oaks on the seashore, on apothecia of Physcia aipolia on bark of young Quercus robur, 28.04.2018, leg. DH \& IS (BILAS) [R $\mathrm{R}_{1}$. New to $\mathrm{SPb}$. Distribution in Northwestern European Russia outside of $\mathrm{SPb}$ : Republic of Karelia (Fadeeva et al., 2007). Distribution in Fennoscandia and Baltic countries: Finland (Nordin et al., 2011), not recorded in Baltic countries. Characterized by a narrow host range (Physcia spp.) and by coarsely verrucose conidia, which are very variable in shape and distinctly tapered at the base (Hawksworth, 1977, Kocourková, Boom, 2005).

\# Lichenodiplis lecanorae (Vouaux) Dyko \& D. Hawksw. - 6: 6008'00.5”N, 2956'08.5”E, seashore vegetation with pines, willows, poplars, rowans, and dog rose, on apothecia of Athallia pyracea on bark of Populus tremula, 03.06.2018, leg. EK \& IS (BILAS) $\left[R_{1}\right]$. New to $S P b$, previously known from ELR and WLR (Stepanchikova et al., 2017a, 2018; Himelbrant et al., 2018).

\# Lichenostigma MaUReri Hafellner - 11: disturbed pine forest on the seashore, on thallus of Bryoria fuscescens on bark of Betula sp., 06.08.2002, leg. O. A. Kataeva (LE s. n.); 14: mixed forest, on thalli of Bryoria capillaris and B. fuscescens on bark of Pinus sylvestris, 05.06.1995, leg. N. V. Malysheva (LE L-13697, sub Bryoria fuscescens; L-13700, sub B. capillaris). New to $\mathrm{SPb}$, previously known from ELR and WLR (Kuznetsova et al., 2016; Himelbrant et al., 2018; Stepanchikova et al., 2019).

Melanelixia Glabratula (Lamy) Sandler \& Arup - on bark of deciduous trees; 1-5, 7-9 [R]; 33, 34.

Melanelixia subaurifera (Nyl.) O. Blanco et al. - on bark and wood; 1-5, 7-10 [O]; 18, 29, 33, 37, 38.

Melanohalea exasperata (De Not.) O. Blanco et al. - on bark and wood; 1-11 [R]; 38.

Melanohalea eXasperatula (Nyl.) O. Blanco et al. - on bark, granite and concrete; 1-11, 13, 14, 16 [O]; 18, 29, 33, 37, 38.

Melanohalea olivacea (L.) O. Blanco et al. - on bark, wood, and granite; 1-7, 9-11, 14 [O]; $18,20,21,24,29,33,34,37,38$.

Melanohalea SePtentrionalis (Lynge) O. Blanco et al. - on bark of Alnus glutinosa, Betula sp., Salix sp., and Sorbus aucuparia; 2, 4, 9, 11, 13 [R]; 21.

Micarea botryoides (Nyl.) Coppins - 8: $60^{\circ} 12^{\prime} 49^{\prime \prime} \mathrm{N}, 29^{\circ} 37^{\prime} 20^{\prime \prime} \mathrm{E}$, spruce forest with pines and spots of Oxalis acetosella, on soil, 19.06.2010, leg. EK \& IS (H) $\left[R_{1}\right]$. New to $S P b$, previously known from WLR (Stepanchikova et al., 2017a; Himelbrant et al., 2018).

Micarea byssacea (Th. Fr.) Czarnota et al. 7: $60^{\circ} 11^{\prime} 11^{\prime \prime} \mathrm{N}, 29^{\circ} 45^{\prime} 49^{\prime \prime} \mathrm{E}$, mixed forest with black alder, on bark of Alnus glutinosa, 07.05.2017, leg. DH \& IS (H); 8: $60^{\circ} 12^{\prime 29} .2^{\prime \prime} \mathrm{N}, 29^{\circ} 34^{\prime} 51.8^{\prime \prime} \mathrm{E}$, moist black alder forest, on bark of Alnus glutinosa, 03.05.2016, leg. DH \& IS (LE), 60¹2'45.1”N, $29^{\circ} 35^{\prime} 00.0^{\prime \prime} \mathrm{E}$, pine forest with feather mosses, on bark of Pinus sylvestris, 03.05.2016, leg. DH \& IS (LE); [R]. Thalli contain meth- 
oxymicareic acid. New to $\mathrm{SPb}$, previously known from WLR (Stepanchikova et al., 2017a, 2019; Himelbrant et al., 2018).

Micarea contexta Hedl. - 8: 60¹2'54.7”N, $29^{\circ} 36^{\prime} 11.1^{\prime \prime} \mathrm{E}$, pine-spruce forest with Sphagnum sp. and Vaccinium myrtillus, on wood of Picea abies, 06.05.2016, leg. EK \& IS $(H)\left[R_{1}\right]$. New to $S P b$, previously known from WLR (Himelbrant et al., 2018).

MICAREA CZARNOTAE Launis et al. - 2: 6000'40.9"N, $29^{\circ} 59^{\prime} 21.7$ "E, spruce forest with feather mosses and Vaccinium myrtillus, on resin of Picea abies, 20.05.2018, leg. DH, EK \& IS (H), 6000'39.8” N, 2959'03.2” E, birch forest with ferns and grasses, on bark of Picea abies, 20.05.2018, leg. DH, EK \& IS (LE); 9: $60^{\circ} 12^{\prime} 10.6 ” \mathrm{~N}, 29^{\circ} 32^{\prime} 19.0^{\prime \prime} \mathrm{E}$, pine forest with mosses and Vaccinium myrtillus, on bark of Pinus sylvestris, 03.09.2016, leg. DH \& IS (LE) [R]. Thalli contain methoxymicareic acid. New to Russia. Distribution in Fennoscandia and Baltic countries: Finland (Launis et al., 2019b). In Western Europe the species is also known from Netherlands and Poland (Launis et al., 2019b). Micarea czarnotae belongs to the $M$. micrococca group and is characterized by numerous, small, plane or hemispherical, cream-white or brownish apothecia with a greyish tinge (Sedifoliagrey) and absence of crystalline granules in thallus (Launis et al., 2019b).

Micarea Denigrata (Fr.) Hedl. - on bark of Betula sp. and Pinus sylvestris, on wood of conifers; 2, 6-9 [R]; 21. Thalli contain gyrophoric acid.

Micarea elachista (Körb.) Coppins \& R. Sant. - on bark of Pinus sylvestris and on wood; $1,3,6[R]$.

MiCAREA ERRATICA (Körb.) Hertel et al. - on granite; 2, 8 [R]; 27.

! Micarea fallax Launis \& Myllys - 8: 60¹2’49”N, $29^{\circ} 37^{\prime} 20^{\prime \prime} \mathrm{E}$, spruce forest with pines and spots of Oxalis acetosella, on wood and bark of Pinus sylvestris, 19.06.2010, leg. EK \& IS (H) $\left[R_{1}\right]$. Thallus contains micareic acid. New to Northwestern European Russia, in Russia known from Arkhangelsk Region (Tarasova et al., 2020). Distribution in Fennoscandia and Baltic countries: Sweden, Finland (Launis et al., 2019a). Micarea fallax differs from $M$. prasina s. str. mainly by having crystals in hymenium which are detectable in polarized light, poorly developed thallus (if growing on wood), and preference of bark as a substrate. $M$. fallax is also similar to $M$. laeta, but differs by producing micareic acid and having brownish or grayish pigmented, often hemisphaerical apothecia (Launis et al., 2019a).

Micarea melaena (Nyl.) Hedl. - on bark and wood of conifers, on bark of Betula sp. and Sorbus aucuparia, on plant debris; 3, 6-8, $11,14,16[R]$.

MicAREA MiCROAREOLATA Launis et al. - on bark and wood of Picea abies and Pinus sylvestris; 2, 3, 8 (Konoreva et al., 2019) [R]. Thalli contain methoxymicareic acid.

MicAREA MicROCOCCA (Körb.) Gams ex Coppins s. str. - on bark of Alnus glutinosa and Pinus sylvestris; 2, 8 [R]. Thalli contain methoxymicareic acid.

MiCAREA MISELLA (Nyl.) Hedl. - on bark of conifers and on wood; $1-4,6-9$ [R]. No lichen substances detected by TLC.

Micarea nitschKeAna (J. Lahm ex Rabenh.) Harm. - on bark and wood of Pinus sylvestris; 7, $11\left[\mathrm{R}_{1}\right]$.

Micarea PEliocarpa (Anzi) Coppins \& R. Sant. on bark of Pinus sylvestris and on wood of Salix sp.; 6, 9 [R].

MicAREA PRASINA Fr. s. str. - on bark of Picea abies, Pinus sylvestris, wood of conifers, wood of Quercus robur, 2, 3, 8 [R]. Thalli contain micareic acid.

Micarea soralifera Guz.-Krzemín. et al. - 8: $60^{\circ} 12 ' 29.2$ "N, 29³4'51.8” E, moist black alder forest, on wood, 03.05.2016, leg. DH $\&$ IS (LE) $\left[\mathrm{R}_{1}\right]$. Thalli contain micareic acid. New to European Russia, the nearest locality is known in the Russian Caucasus (Urbanavichus, Urbanavichene, 2017). Distribution in Fennoscandia and Baltic countries: Sweden, Finland (Nordin et al., 2011). The species belongs to the $M$. prasina group and is characterized by having distinct soralia and containing micareic acid (GuzowKrzemińska et al., 2016).

Micarea tomentosa Czarnota \& Coppins - on bark of Picea abies; 3: 6004'16.0” N, $29^{\circ} 57^{\prime} 41.1^{\prime \prime} \mathrm{E}$, pine-spruce forest with mosses, Vaccinium myrtillus, Oxalis acetosella, and Calamagrostis sp., with spruce undergrowth, 28.04.2018, leg. DH \& IS (LE); 7: 60¹1'11"N, 2945'49”E, mixed forest with black alder, on bark of Alnus glutinosa, 07.05.2017, leg. DH \& IS (H); [R]. New to Northwestern European Russia, 
nearest localities in the European Russia are known in Arkhangel'sk and Moscow regions (Muchnik et al., 2019; Tarasova et al., 2020). Distribution in Fennoscandia and Baltic countries: Sweden, Finland (Nordin et al., 2011), Estonia (Randlane et al., 2019). Characterized by stalked pycnidia covered with whitish tomentum, and by absence of lichen substances (Czarnota, 2007). Similar to Micarea hedlundii but differs in larger thalline granules, brownish, usually simple, convex to hemispherical, often adnate apothecia, and the absence of the dull orange Intrusa-yellow pigment (reacting $\mathrm{K}+$ violet, $\mathrm{C}+$ violet) in thallus.

$!^{*}(\#)$ Microcalicium disseminatum (Ach.) Vain. - 8: $60^{\circ} 11^{\prime} 59.7^{\prime \prime} \mathrm{N}, 2^{\circ} 33^{\prime} 30^{\prime \prime} \mathrm{E}$, larch stand, on bark of Larix sp., 01.05.2016, leg. DH \& IS (LECB s. n.) $\left[\mathrm{R}_{1}\right] ; 34$, on thallus of Chaenotheca ferruginea on bark of coniferous tree (Stepanchikova et al., 2014).

! Montanelia sorediata (Ach.) Divakar et al. - on granite; 1, 6, 9 [R].

\# Muellerella ventosicola (Mudd) D. Hawksw. - 6: 6008'06.4”N, 2956’51.5”E, disturbed pine forest, on thallus of sterile crustose lichen on granite boulder, 03.06.2018, leg. EK \& IS (BILAS) $\left[\mathrm{R}_{1}\right]$. - New to $\mathrm{SPb}$, previously known from WLR (Himelbrant et al., 2019).

Mycobilimbia CARNEOALBIDA (Müll. Arg.) S. Ekman \& Printzen - on bark of Populus tremula; 9 (Stepanchikova et al., 2014) $\left[R_{1}\right]$.

MycoBILIMBIA EPIXANTHOIDES (Nyl.) Vitik. et al. - on mosses on bark of Alnus incana, Populus tremula, Sorbus aucuparia; 4, 7, 9 [R].

$\dagger$ Mycobilimbia pilularis (Körb.) Hafellner \& Türk - on wood; 24 (Elenkin \& Beketov, 1919, as Bilimbia sphaeroides (Dicks.) Th. Fr.; no specimens found). This locality is the only one reported from $\mathrm{SPb}$, but the species is known from Karelian Isthmus (Vainio, 1878).

Mycoblastus alpinus (Fr.) Th. Fr. ex Hellb. - 8: $60^{\circ} 12^{\prime} 47.6^{\prime \prime} \mathrm{N}, 29^{\circ} 36^{\prime} 00.7^{\prime \prime} \mathrm{E}$, swampy pine forest with Ledum palustre, on bark of Betula sp., 06.05.2016, leg. EK \& IS (LECB s. n.) $\left[R_{1}\right]$.

! Mycoblastus sanguinarius (L.) Norman - 8: $60^{\circ} 12^{\prime} 47.6^{\prime \prime} \mathrm{N}, 29^{\circ} 36^{\prime} 00.7^{\prime \prime} \mathrm{E}$, swampy pine forest with Ledum palustre, on bark of Betula sp., 06.05.2016, leg. EK \& IS (LECB s. n.) $\left[\mathrm{R}_{1}\right]$; 17: on bark of Pinus sylvestris (Elenkin \& Beketov, 1919).
+ Mycocalicium subtile (Pers.) Szatala - on wood; 1-9 [R]; 34.

+ Mycomicrothelia wallrothit (Hepp) D. Hawksw. - on bark of Betula sp.; 9 (Stepanchikova et al., 2014) $\left[R_{1}\right]$.

Myriolecis Albescens (Hoffm.) Śliwa et al. - on concrete; 2, 9 [R].

Myriolecis CRENUlata (Hook.) Śliwa et al. - on concrete; 8, 13, 14, 16 [R].

Myriolecis DISPERSA (Pers.) Śliwa et al. - on granite and concrete; 1-3, 5, 8-10, 14, 16 [R].

MYRIOLECIS HAGENII (Ach.) Śliwa et al. - on bark of deciduous trees, rarely on wood and granite; 1-11, 13, 14, 16 [O]; 29, 33.

Myriolecis sambuci (Pers.) Clem. - on bark of Populus tremula, Sambucus racemosa, and Sorbus aucuparia; 3 [ $\left.\mathrm{R}_{1}\right]$; 18, 33, 38.

Myriolecis SEMIPALlida (H. Magn.) Śliwa et al. - on concrete; 2, 4, 8 [R].

NAEtrocymbe Punctiformis (Pers.) R. C. Harris - on smooth bark of deciduous trees; $1-5$, 7-9 [R]; 21.

NAETROCYMBE RHYPONTA (Ach.) R. C. Harris - on bark of Acer platanoides; 9 (Stepanchikova et al., 2014) $\left[R_{1}\right]$.

!§† NePHROMA PARILE (Ach.) Ach. - on mosses; 34 (Stepanchikova et al., 2014).

!§† Nephroma REsupinatum (L.) Ach. - on mosses; 34 (Stepanchikova et al., 2014).

OCHROLECHIA ALBOFLAVESCENS (Wulfen) Zahlbr. - 3: $60^{\circ} 03^{\prime} 52.8^{\prime \prime} \mathrm{N}, 2^{\circ} 57^{\prime} 07.5^{\prime \prime} \mathrm{E}$, oaks on seashore, on bark and wood of Quercus robur, 28.04.2018, leg. DH \& IS (LECB s. n.) [ $\left.\mathrm{R}_{1}\right]$. Thalli contain variolaric, lichesterinic, and protolichesterinic acids.

OCHROLECHIA BAHUSIENSIS H. Magn. - on bark of Alnus glutinosa and Sorbus aucuparia; 3, 5, 7, 8 [R]. Thalli contain lecanoric, gyrophoric acids, and murolic acid complex.

OCHROLECHIA MICROSTICTOIDES Räsänen - on bark of Alnus glutinosa and Pinus sylvestris; 4, 8 [R]. Thalli contain variolaric, lichesterinic acids, and "microstictoides unknowns".

$\dagger$ Opegrapha vulgata (Ach.) Ach. - on bark of deciduous tree; 34 (Stepanchikova et al., 2014).

Palicella filamentosa (Stirt.) Rodr. Flakus \& Printzen - on bark and wood of conifers; 6-9 [R].

PARMELIA SULCATA Taylor - on bark, more rarely on wood, granite, and concrete; 1-11, 13, 14, 16 [C]; 18, 20, 21, 24, 29, 33, 34, 37, 38. 
Parmeliopsis Ambigua (Wulfen) Nyl. - on bark and wood, rarely on granite; $1-11,13,14,16$ [C]; $17,20,21,29,33,34,37,38$.

PARMELIOPSIS HYPEROPTA (Ach.) Arnold - on bark and wood; 1, 3, 6-9, 11, 14 [O]; 17, 33.

! Peltigera aphthosa (L.) Willd. - on soil; 7, 8 [R]; 17, 20, 24, 33, 37.

Peltigera Canina (L.) Willd. - on soil, concrete, and mosses; 1-3, 6, 9, 11, 13, 14 [R]; 17, 24, 33, 37.

Peltigera Didactyla (With.) J. R. Laundon - on bark of Salix sp., soil, and mosses; 1, 2, 6, 8, 9, 11, 13, 14, 16 [R]; 20, 33, 37, 38.

Peltigera eXtenuata (Nyl. ex Vain.) Lojka - on soil and on wood of Pinus sylvestris; 1, 2, 6, 9 [R].

$! \uparrow$ Peltigera leucophlebia (Nyl.) Gyeln. - on soil; 21 (Malysheva, 2003), 37 (Fagerström, 1945, as $P$. variolosa (Mass.) Körb.).

$\dagger$ Peltigera malacea (Ach.) Funck - on soil; 17 (Elenkin \& Beketov, 1919), 33 (Savicz, 1910; Malysheva, 1999, 2003).

$\dagger$ Peltigera NeCKeri Hepp ex Müll. Arg. - 29, on bark of Sorbus aucuparia, 03.06.1938, leg. Fagerström L., det. Vitikainen O., 1977 (Vitikainen, 1994 (map); H 8000604).

Peltigera NEOPOLYdactyla (Gyeln.) Gyeln. - on soil; 7 [R].

Peltigera polydactylon (Neck.) Hoffm. - on soil and mosses; 6, 11, $13\left[\mathrm{R}_{1}\right] ; 20,21$. The specimen from 29 (Fagerström, 1945) refers to $P$. neckeri.

$\dagger$ Peltigera ponojensis Gyeln. - 19, on soil, 05.07.1939, leg. Fagerström L., det. Vitikainen O., 1979 (Vitikainen, 1994 (map); H 8000630).

Peltigera PRAETEXTATA (Flörke ex Sommerf.) Zopf - on bark of Populus tremula, soil, mosses; 2, 3, 8, 9, 11 [R]; 34.

Peltigera Rufescens (Weiss) Humb. - on soil and mosses; 1, 2, 8, 9, 13, 14 [R]; 17, 20, 24, 38. The specimen from 19 (Fagerström, 1945) refers to $P$. ponojensis.

Pertusaria CARneOPallida (Nyl.) Anzi ex Nyl. - on bark of Sorbus aucuparia; 8, 9 [R].

!* Pertusaria coccodes (Ach.) Nyl. - on bark and wood of Quercus robur, 1, 3 [R].

Pertusaria PUPILlaris (Nyl.) Th. Fr. - on bark of Alnus spp., Betula sp., Padus avium, and Sorbus aucuparia; 1, 2, 7-9 [R].

+ Phaeocalicium polyporaeum (Nyl.) Tibell - on fruit bodies of Trichaptum biforme (Fr.) Ryvarden; 1, $6[\mathrm{R}]$.
Phaeophyscia ciliata (Hoffm.) Moberg - on bark of Acer platanoides, Populus spp., Viburnum opulus, and Lonicera xylosteum; 1-3, 6, 9, 13 [R]; 18, 29, 33.

PHAEOPHYSCIA NIGRICANS (Flörke) Moberg - on bark of deciduous trees and on concrete; $1-6,8$, $9,16[R]$.

PhAEOPHYSCIA ORBICUlARIS (Neck.) Moberg - on bark of deciduous trees, on wood, granite, slate, concrete, and iron; 1-6, 8-10, 13, 14, $16[\mathrm{O}] ; 18,29,33$.

PhAEOPHYSCIA SCIASTRA (Ach.) Moberg - on granite, concrete and bark of Populus tremula; $1-3,8[R]$.

Phlyctis ARgena (Spreng.) Flot. - on bark of deciduous trees; 1-10, 14 [O]; 23, 34.

Physcia ADSCEndens H. Olivier - on bark of deciduous trees, wood of Pinus sylvestris, and concrete; 1-9, 11, 13, 14, 16 [O]; 18, 29, 33, 37, 38.

Physcia Aipolia (Ehrh. ex Humb.) Fürnr. - on bark of deciduous trees; 1-9, 16 [O]; 27, 29, 33, 37.

PhysCIA ALNOPHILA (Vain.) Loht. et al. - on bark of Alnus glutinosa, Populus tremula, Quercus robur, Salix spp.; 2-6, 9 [R].

Physcia CAESIA (Hoffm.) Fürnr. - on bark of Alnus glutinosa, Populus sp., Populus tremula, Quercus robur, Salix sp., on granite, concrete, and iron; 1-5, 8-10, 14 [R].

Physcia DUBIA (Hoffm.) Lettau - on bark of deciduous trees and Picea abies, wood of Pinus sylvestris, granite, and concrete; 1-5, 7-10, 13, 14, 16 [R]; 33.

PHYSCIA STELLARIS (L.) Nyl. - on bark of deciduous trees, on concrete; $1,2,4-6,8-11,13,14$, 16 [R]; 21, 27, 29, 33, 37, 38.

Physcia TEnella (Scop.) DC. - on bark and wood, upturned roots, granite, and concrete; 1-10, 13, 14, 16 [O]; 29, 33, 37, 38.

Physconia Detersa (Nyl.) Poelt - on bark of Populus alba and Quercus robur; 5 [R].

PHYSCONIA DISTORTA (With.) J. R. Laundon - on bark of Acer platanoides, Populus spp., Quercus robur, Salix sp., and Tilia sp.; 1-4, $6,8,9,11,13,14,16[\mathrm{R}] ; 18,29,30,33$, $37,38$.

Physconia enteroxantha (Nyl.) Poelt - on bark of deciduous trees; $1,2,4,5,8,9$ [R]; 18, 29, 38.

PhysCONIA PERISIDIOSA (Erichsen) Moberg - 8: $60^{\circ} 11^{\prime} 49.5^{\prime \prime} \mathrm{N}, 29^{\circ} 33^{\prime} 35.2 ” \mathrm{E}$, poplar alley, 
on bark of Populus alba, 01.05.2016, leg. DH \& IS (LECB s. n.) [R $\mathrm{R}_{1}$.

PiCCOLIA OCHROPHORA (Nyl.) Hafellner - on bark of Acer platanoides and Populus tremula; $6,9[\mathrm{R}]$.

Placynthiella dasaea (Stirt.) Tønsberg - on wood, soil, plant debris, upturned roots, on bark of Betula sp., Picea abies, Populus alba, Quercus robur, Salix spp., and Sorbus aucuparia; 1, 3-9 [R].

PlacynthiElla ICMALEa (Ach.) Coppins \& P. James - on wood, soil, plant debris, mosses, granite, and bark of trees; 1-4, 6-9 [O]; 29, 33.

Placynthiella oligotropha (J. R. Laundon) Coppins \& P. James - 6: 6006'36.4”N, $29^{\circ} 57^{\prime} 37.9$ " $\mathrm{E}$, disturbed pine forest on sandy river bank, on sandy soil, 04.06.2018, leg. EK \& IS (LECB s. n.) [R]

Placynthiella uliginosa (Schrad.) Coppins \& P. James - on sandy soil, mosses, wood, bark of Padus avium and Quercus robur, 1-3, 6-9, 11 [R]; 24, 29.

Placynthium Nigrum (Huds.) Gray - 3: $60^{\circ} 04^{\prime 2} 2.7^{\prime \prime} \mathrm{N}, 2^{\circ} 57^{\prime} 32.8^{\prime \prime} \mathrm{E}$, concrete block near the road, on concrete, 28.04.2018, leg. DH \& IS (LECB s. n.) [ $\left.\mathrm{R}_{1}\right]$.

Platismatia glauca (L.) W. L. Culb. \& C. F. Culb. - on bark and wood, rarely on granite; 1-9, 11, 14-16 [F]; 21, 24, 29, 33, 37, 38.

Polycauliona Candelaria (L.) Frödén et al. - on bark of deciduous trees; 3-5, 7, 9 [R]; 21, 33.

Polycauliona POlYCARPa (Hoffm.) Frödén et al. on bark, wood, granite, concrete; 1-11, 13, 14, 16 [F]; 18, 21, 24, 27, 33, 37, 38.

Porina lePtalea (Durieu \& Mont.) A. L. Sm. - 8: $60^{\circ} 12 ’ 27^{\prime \prime} \mathrm{N}, 2^{\circ} 37^{\prime} 33^{\prime \prime} \mathrm{E}$, floodplain deciduous forest with bird cherry undergrowth, on bark of Sorbus aucuparia, 19.06.2010, leg. EK \& IS (LECB s. n.) [R ${ }_{1}$. New to $\mathrm{SPb}$, previously recorded from WLR (Himelbrant et al., 2017).

Porpidia CRUSTUlata (Ach.) Hertel \& Knoph - on granite; $1-3,8,9[R]$.

Porpidia maCRocarpa (DC.) Hertel \& A. J. Schwab - on granite; $1,6,8,9$ [R].

PorPidia SOREDIZODEs (Lamy ex Nyl.) J. R. Laundon - on granite; 2, 3, 8 [R]. Thalli contain stictic acid complex.

Porpidia tuberculosa (Sm.) Hertel \& Knoph - on granite; 9 (Stepanchikova et al., 2014) [ $\left.R_{1}\right]$.

PROTOBLASTENIA RUPESTRIS (Scop.) J. Steiner - 8: $60^{\circ} 12^{\prime} 27^{\prime \prime} \mathrm{N}, 29^{\circ} 37^{\prime} 33^{\prime \prime} \mathrm{E}$, floodplain deciduous forest with bird cherry undergrowth, on concrete, 19.06.2010, leg. EK \& IS (LECB s. n.) $\left[R_{1}\right]$.

PROTOPARMELIOPSIS MURALIS (Schreb.) M. Choisy on granite, concrete; 2, 9, 14 [R].

PROTOTHELENElla CORROSA (Körb.) H. Mayrhofer $\&$ Poelt - on granite; 9 (Stepanchikova et al., 2014) $\left[R_{1}\right]$.

PseudeVernia FURfuracea (L.) Zopf - on bark and wood, once on soil; $1-9,11,14,16$ [O]; 17, 20, 21, 23, 29, 33, 37, 38.

Pseudosagedia aenea (Wallr.) Hafellner \& Kalb. on bark of Betula sp., Padus avium, Sorbus aucuparia, Vaccinium myrtillus; 2, 7, 8 [R].

Pseudosagedia CHLOROTICA (Ach.) Hafellner \& Kalb - on granite and iron; 1, 2, 4 [R].

Pseudoschismatomma Rufescens (Pers.) Ertz \& Tehler - on bark of Alnus glutinosa, Populus spp., and Ulmus sp.; 1, 6, 8, 11, 13 [R].

Psilolechia Clavulifera (Nyl.) Coppins - on upturned roots, wood, bark of Alnus glutinosa, Picea abies, and Pinus sylvestris; 1, 3, 7, $8[\mathrm{R}]$.

Psilolechia lucida (Ach.) M. Choisy - on upturned roots, bark, and wood of conifers; 2 , 3, 6-8, 11 [R]; 18.

Psoroglaena Dictyospora (Orange) H. Harada - on soil, mosses, and dead thallus of Peltigera sp. on soil; 1 (Stepanchikova et al., 2008, as Leucocarpia dictyospora (Orange) R. Sant.) $\left[R_{1}\right]$.

PSOROTICHIA SCHAERERI (A. Massal.) Arnold - on concrete; 9 (Stepanchikova et al., 2014) [ $\left.R_{1}\right]$.

PyCNORA PRAESTABILIS (Nyl.) Hafellner - on bark of Pinus sylvestris; 9 (Stepanchikova et al., 2014) $\left[R_{1}\right]$.

PYCNORA SOROPHORA (Vain.) Hafellner - on bark and wood of conifers, bark of Alnus glutinosa and Betula sp.; 2, 6-9 [R].

! Pycnothelia papillaria (Ehrh.) Dufour - 8: $60^{\circ} 11^{\prime} 56.4^{\prime \prime} \mathrm{N}, 29^{\circ} 34^{\prime} \mathrm{O} 6.3$ " $\mathrm{E}$, pine forest on the top of steep sandy slope, on primary soil, 01.05.2016, leg. DH \& IS (Red..., 2018; LECB s. n.) $\left[R_{1}\right]$.

!§ Ramalina BaLtica Lettau - 3: 6003'52.8” N, $29^{\circ} 57^{\prime} 07.5^{\prime \prime} \mathrm{E}$, seashore, on bark of old Quercus robur, 20.04.2018, leg. EK \& IS (LECB s. n.) $\left[R_{1}\right]$. The species was erroneously reported from 35 (Malysheva, 2003).

! Ramalina dilacerata (Hoffm.) Hoffm. - 3: $60^{\circ} 03^{\prime} 53.8^{\prime \prime} \mathrm{N}, 29^{\circ} 57^{\prime} 19.8^{\prime \prime} \mathrm{E}$, glade with $\mathrm{Sa}$ lix $\times$ fragilis, young aspens, and shrubs, on bark of Syringa vulgaris, 29.04.2018, leg. DH \& IS (LECB s. n.) [R $]$; 24: on branches 
of Picea abies (Elenkin \& Beketov, 1919), 30: on bark of Populus balsamifera (Ahlner, 1948), 38: on bark of Betula sp. (Fagerström, 1945; Malysheva, 2003).

Ramalina EuRopaea Gasparyan et al. - 1: 59 59'57.1"N, 3002'03.1"E, seashore, on bark of old logged Quercus robur, 08.05.2019, leg. DH \& IS (LECB s. n.) [R ${ }_{1}$. New to $\mathrm{SPb}$. Distribution in Northwestern European Russia outside of SPb: Novgorod Region (Czernyadjeva et al., 2019). Distribution in Fennoscandia and Baltic countries: not reported. Differs from $R$. pollinaria by numerous spine-like terminal and marginal branchlets with punctiform soralia on the top (Gasparyan et al., 2017).

RAMALINA FARINACEA (L.) Ach. - on bark of deciduous trees; 1-10, 14 [O]; 18, 20, 21, 24, 29, 30, 33, 34, 35, 37, 38.

RAMALINA FRAXINEA (L.) Ach. - on bark of deciduous trees; 1-5, 9, 14 [R]; 18, 29, 33, 37, 38.

RAMALINA POLLINARIA (Westr.) Ach. - on bark of deciduous trees; 1, 3, 5, 10, 14 [R]; 24.

! RAMALINA SINENSIS Jatta - on bark of Populus spp., Quercus robur, and Sorbus aucuparia; 3, 4 [R]; 20, 29, 33, 37.

!§† RAMAlina thrausta (Ach.) Nyl. - on bark of Picea abies; 34 (Stepanchikova et al., 2014).

RAmboldia CinNaBARINA (Sommerf.) Kalb et al. - on bark of Populus tremula; 9 (Stepanchikova et al., 2014) $\left[R_{1}\right]$.

RAMONIA HIMELBRANTII Gagarina - 8: 60¹2'47.6”N, $29^{\circ} 36^{\prime} 00.7$ 'E, swampy pine forest with $L e$ dum palustre, on wood of Pinus sylvestris, 06.05.2016, leg. EK \& IS (LECB s. n.) [R $]$. New to $\mathrm{SPb}$, previously known from ELR (Himelbrant et al., 2018).

RhizocarPon BadiOATRUM (Flörke ex Spreng.) Th. Fr. - 2: 6000'36.6” N, 2957'50.8” E, young aspen stand with dog rose on a boulder pier, on granite, 06.05.2018, leg. DH, EK \& IS (H); 6: $60^{\circ} 08^{\prime} 06.4^{\prime \prime} \mathrm{N}, 29^{\circ} 56^{\prime} 51.5 ” \mathrm{E}$, pine forest, on granite boulder, 03.06.2018, leg. EK \& IS $(\mathrm{H}) ;[\mathrm{R}]$. New to $\mathrm{SPb}$, previously known from ELR and WLR (Kuznetsova et al., 2007; Himelbrant et al., 2018; Stepanchikova et al., 2019).

RHIZOCARPON DISTINCTUM Th. Fr. - on granite; 9 (Stepanchikova et al., 2014) $\left[\mathrm{R}_{1}\right]$.

RHIZOCARPON GEMINATUM Körb. - 2: 6000'36.6”N, $29^{\circ} 57^{\prime} 50.8^{\prime \prime} \mathrm{E}$, young aspen stand with dog rose on a boulder pier, on granite, 06.05.2018, leg. DH, EK \& IS (H) $\left[R_{1}\right]$. New to
$\mathrm{SPb}$, previously known from WLR (Alexeeva \& Himelbrant, 2007).

RHIZOCARPON GEOGRAPHICUM (L.) DC. - 2 : $60^{\circ} 00^{\prime} 36.6^{\prime \prime} \mathrm{N}, 29^{\circ} 57^{\prime} 50.8^{\prime \prime} \mathrm{E}$, young aspen stand with dog rose on a boulder pier, on granite, 06.05.2018, leg. DH, EK \& IS (LECB s. n.) $\left[R_{1}\right] ; 37$ (Fagerström, 1945).

RHIZOCARPON GRANDE (Flörke ex Flot.) Arnold - on granite; 6, 8 [R].

Rhizocarpon laVatum (Fr.) Hazsl. - on granite; $1-3,6,8,9[R]$.

RHIZOCARPON MACROSPORUM Räsänen - 2 : $60^{\circ} 00^{\prime} 36.6^{\prime \prime} \mathrm{N}, 2^{\circ} 57^{\prime} 50.8^{\prime \prime} \mathrm{E}$, young aspen stand with dog rose on a boulder pier, on granite, 06.05.2018, leg. DH, EK \& IS (H); 8: $60^{\circ} 12^{\prime} 12.0^{\prime \prime} \mathrm{N}, 29^{\circ} 34^{\prime} 35.1^{\prime \prime} \mathrm{E}$, in pine forest, on granite boulder, 03.05.2016, leg. DH \& IS (LECB s. n.), 60¹3’09”N, 29³7'00”E, disturbed pine forest with mosses, on granite boulder, 06.06.2010, leg. DH, EK \& IS (LECB s. n.); [R]. New to SPb, previously known from WLR (Himelbrant et al., 2018; Stepanchikova et al., 2019).

RHIZOCARPON POLYCARPUM (Hepp) Th. Fr. - 8: $60^{\circ} 13^{\prime} 09^{\prime \prime} \mathrm{N}, 2^{\circ} 37^{\prime} 00^{\prime} \mathrm{E}$, disturbed pine forest with mosses, on granite, 06.06.2010, leg. DH, EK \& IS (LECB s. n.) [R $]$. New to $\mathrm{SPb}$, previously known from ELR and WLR (Kuznetsova et al., 2007; Himelbrant et al., 2018; Stepanchikova et al., 2019).

Rinodina EXIGUA (Ach.) Gray - on bark of Alnus sp.; 13 (Malysheva, 1993, 2003).

Rinodina milvina (Wahlenb.) Th. Fr. - 2: $60^{\circ} 00^{\prime} 36.6 ” \mathrm{~N}, 29^{\circ} 57^{\prime} 50.8^{\prime \prime} \mathrm{E}$, young aspen stand with dog rose on a boulder pier, on granite, 06.05.2018, leg. DH, EK \& IS (H) $\left[\mathrm{R}_{1}\right]$. New to $\mathrm{SPb}$, previously known from ELR and WLR (Alexeeva \& Himelbrant, 2007; Kuznetsova et al., 2007).

RiNODINA PYRINA (Ach.) Arnold - on bark of deciduous trees; 1-4, 6, 9, 11 [R]; 38.

RINODINA SEPTENTRIONALIS Malme - on bark of deciduous trees; 1-5, 8, 9 [R]; 33.

Rinodina sophodes (Ach.) A. Massal. - on bark of Alnus glutinosa, Padus avium, Salix sp., and Sorbus aucuparia; 4, 7 [R].

RiNODINA SUBPARIETA (Nyl.) Zahlbr. - on bark of Quercus robur, 1 (Stepanchikova et al., 2008, as $R$. degeliana Coppins) $\left[R_{1}\right]$.

ROPALOSPORA VIRIDIS (Tønsberg) Tønsberg - on bark of deciduous trees; 1-9 [O].

Rufoplaca arenaria (Pers.) Arup et al. - 2: $60^{\circ} 00^{\prime} 36.6 ” \mathrm{~N}, 29^{\circ} 57^{\prime} 50.8^{\prime \prime} \mathrm{E}$, young aspen 
stand with dog rose on a boulder pier, on granite, 06.05.2018, leg. DH, EK \& IS (H) $\left[\mathrm{R}_{1}\right]$.

RusAVSKIA ELEGANS (Link) S. Y. Kondr. \& Kärnefelt - on concrete and granite; 3, 8, 9 [R].

SARCOGYNe hypophaEa (Nyl.) Arnold - 3: $60^{\circ} 04^{\prime} 28.7 ” \mathrm{~N}, 2^{\circ} 57^{\prime} 32.8^{\prime \prime} \mathrm{E}$, on concrete block near the road, 28.04.2018, leg. DH \& IS $(H)\left[R_{1}\right]$. New to $\mathrm{SPb}$. Distribution in Northwestern European Russia outside of $\mathrm{SPb}$ : Republic of Karelia (Fadeeva et al., 2007). Distribution in Fennoscandia and Baltic countries: Norway, Sweden, Finland (Nordin et al., 2011), Estonia (Randlane et al., 2019). The species was erroneously reported from 1 (Stepanchikova et al., 2008; as S. privigna (Ach.) A. Massal.), the specimen refers to $S$. regularis. Differs from other species of the genus by small epruinose red-brown apothecia with colorless hypothecium and elongate ascospores (Foucard, 2001).

SARCOGYNE REGULARIS Körb. - on concrete; 1, 8, $9[\mathrm{R}]$.

Sarcosagium campestre (Fr.) Poetsch \& Schied. - on bark of Betula sp.; 1 (Stepanchikova et al., 2008) $\left[R_{1}\right]$.

+ SAREA DIFFORMIS (Fr.) Fr. - on resin of conifers; $1-4,6-8[R]$.

+ Sarea Resinae (Fr.: Fr.) Kuntze - on resin of conifers; 1-3, 6-8 [R].

!§† SChismatomma PeRicleum (Ach.) Branth $\&$ Rostr. - on bark of Picea abies; 34 (Stepanchikova et al., 2014; Red..., 2018).

!§ SCLEROPHORA CONIOPHAEA (Norman) J. Mattsson \& Middelb. - 1: 6000’00.3”N, 3001'50.2”E, black alder forest with broadleaved trees, on bark of Quercus robur, 08.05.2019, DH \& IS (field record); 5: on bark of Quercus robur (Himelbrant et al., 2014); [R].

Scoliciosporum CHLOROCOCCUM (Graewe ex Stenh.) Vězda - on bark and wood, rarely on concrete; 1-11, 13, 14, 16 [O].

SCOLICIOSPORUM SAROTHAMNI (Vain.) Vězda - on bark and wood; 1-9, 16 [C].

Scoliciosporum umbrinum (Ach.) Arnold - on granite; 2, 3, 6, 8, 9 [R].

SCUTUla CIRCUMSPECTA (Vain.) Kistenich et al. - on bark of Alnus glutinosa; 4, $13\left[\mathrm{R}_{1}\right]$.

$!^{*} \dagger$ Scytinium Lichenoides (L.) Otálora et al. - on wood; 24 (Elenkin \& Beketov, 1919, as Leptogium lacerum).

Staurothele Fissa (Taylor) Zwackh - 2: $60^{\circ} 00^{\prime} 36.6 ” \mathrm{~N}, 29^{\circ} 57^{\prime} 50.8^{\prime \prime} \mathrm{E}$, young aspen stand with dog rose on a boulder pier, on granite, 06.05.2018, leg. DH, EK \& IS (H) $\left[\mathrm{R}_{1}\right]$. New to $\mathrm{SPb}$, previously known from ELR and WLR (Vainio, 1921; Kuznetsova et al., 2007).

Steinia GEOPHANa (Nyl.) Stein - on soil and wood; $1,3,8,9[R]$.

+ Stenocybe pullatula (Ach.) Stein - on bark of Alnus spp.; 1-9 [O]; 29, 34.

STEREOCAULON ALPINUM Laurer - on soil; 6, 8 [R]. Stereocaulon CONDENSATUm Hoffm. - 8 : $60^{\circ} 11^{\prime} 58.3$ " N, $29^{\circ} 34^{\prime} 8.7$ 'E, top of sandy slope, on soil, 01.05.2016, leg. DH \& IS (LECB s. n.) [R ${ }_{1}$; 17 (Elenkin \& Beketov, 1919), 38: 20.08.1939, leg. S. Ahlner (S F-255534).

Stereocaulon paschale (L.) Hoffm. - on soil; 9 (Stepanchikova et al., 2014) [R] ] 17 (Dubyansky, 1910, 1919), 33 (Savicz, 1910; Lemberg, 1933, 1935; Malysheva, 1999, 2003).

STEREOCAULON SAXATILE H. Magn. - 2: 6001'18.3”N, $29^{\circ} 58^{\prime} 41.4 " \mathrm{E}$, anthropogenic wasteland, on granite, 27.05.2018, leg. DH, EK \& IS (LECB s. n.) $\left[R_{1}\right]$.

STEREOCAULON TOMENTOSUm Fr. - on soil, granite, and tarmac; 1, 2, 9 [R]; 17, 21, 22, 27, 33.

\# Stigmidium fuscatae (Arnold) R. Sant. - 2: $60^{\circ} 01^{\prime} 40.6 ” \mathrm{~N}, 2^{\circ} 59^{\prime} 08.7^{\prime \prime} \mathrm{E}$, granite boulders, on squamules of Acarospora fuscata on granite, 02.06.2018, leg. EK \& IS (BILAS, $\mathrm{H})\left[\mathrm{R}_{1}\right]$.

STRANGOSPORA DEPLANATA (Almq.) Clauzade \& $\mathrm{Cl}$. Roux - 6: 6007'57.6”N, 2956'13.9”E, sandy seashore pine forest with graminoids, on wood of Pinus sylvestris, 03.06.2018, leg. EK \& IS (LECB s. n.) [ $\left.R_{1}\right]$.

STRANGOSPORA MORIFORMIS (Ach.) Stein - on bark of Larix sp. and Pinus sylvestris, on wood; 2, 3, 6, 8, 9, 11 [R]; 17, 21, 23.

STRANGOSPORA PINICOLA (A. Massal.) Körb. - on bark of Fraxinus excelsior, Quercus robur, Ulmus sp., on wood; 1, 3 [R].

Strigula JAmesi (Swinscow) R. C. Harris - 3: $60^{\circ} 04^{\prime} 08.2^{\prime \prime} \mathrm{N}, 2^{\circ} 57^{\prime} 18.2^{\prime \prime} \mathrm{E}$, spruce forest with pines, birches, with green mosses and Sphagnum sp., on bark of Sorbus aucuparia, 20.04.2018, leg. EK \& IS (H) $\left[\mathrm{R}_{1}\right]$.

Strigula stigmatella (Ach.) R. C. Harris - 3: $60^{\circ} 04^{\prime} 13.6 ” \mathrm{~N}, 29^{\circ} 56$ '58.5”E, swampy black alder forest with spruces, on bark of $\mathrm{Al}$ nus glutinosa, 20.04.2018, leg. EK \& IS (H); 5: 6005'20.1”N, 2955’52.2”E, open oak stand in park, on bark of Quercus 
robur, 10.06.2018, leg. EK \& IS (LECB s. n.), $60^{\circ} 05^{\prime} 27.4^{\prime \prime} \mathrm{N}, 2^{\circ} 56^{\prime} 11.1^{\prime \prime} \mathrm{E}$, pine-birch forest with rowan, on bark of Betula sp., 16.07.2018, leg. EK (H), 6005'27.5” N, $29^{\circ} 55^{\prime} 53.9^{\prime} \mathrm{E}$, black alder swampy forest with birch, on bark of Alnus glutinosa, 16.07.2018, leg. EK $(\mathrm{H})$; [R]. New to SPb, previously known from WLR (Stepanchikova et al., 2019).

\# TAeniolella Beschiana Diederich - on thallus of Cladonia sp. on soil; 7 (Stepanchikova et al., 2018) $\left[R_{1}\right]$.

Thelenella PERTUSARIELla (Nyl.) Vain. - on bark of deciduous trees; $1-6[\mathrm{R}]$.

THELIDIUM MinUtUlum Körb. - 3: 6004'14.4”N, $29^{\circ} 57^{\prime} 00.3^{\prime \prime} \mathrm{E}$, roadside, on brick, 20.04.2018, leg. EK \& IS (H) [R $]$.

THELOCARPON EPIBOLUM Nyl. - on wood; 1, 7 [R].

THELOCARPON INTERMEDIELLUM Nyl. - on wood; 1 (Himelbrant et al., 2017) [ $\left.\mathrm{R}_{1}\right]$.

$\dagger$ THELOCARPON LAURERI (Flot.) Nyl. - on granite; 36 (Malysheva, 1996, 2003; LE s. n.).

THELOCARPON SUPERELLUM Nyl. - on wood of Picea abies; 8 [R].

Toensbergia Leucococca (R. Sant.) Bendiksby \& Timdal - 8: $60^{\circ} 12^{\prime} 34^{\prime \prime} \mathrm{N}, 2^{\circ} 36^{\prime} 35^{\prime \prime} \mathrm{E}$, pine forest with birches, spruces, and willows, with horsetails and Sphagnum spp., on bark of Salix sp., 06.06.2010, leg. DH, EK \& IS (LECB s. n.) $\left[R_{1}\right]$.

TONinia POPUlORUm (A. Massal.) Kistenich et al. - on bark of Populus spp. and Sorbus aucuparia; 1, 2, 4, 6, 9 [R]; 29.

TONINIOPSIS SUBINCOMPTA (Nyl.) Kistenich et al. - on bark of deciduous trees; 1-3, 7-9 [R]; 24.

TRAPElia COARCTATA (Sm.) M. Choisy - on granite; $8,9[R]$.

Trapelia Glebulosa (Sm.) J. R. Laundon - on granite; 6, 8 [R].

TRAPELIA OBTEGENS (Th. Fr.) Hertel - on granite; 1 (Stepanchikova et al., 2008) $\left[R_{1}\right]$.

TRAPElia Placodioides Coppins \& P. James - on granite; 1-3, 6, 8, 9 [R].

TRAPEliopsis FleXUOSA (Fr.) Coppins \& P. James on wood and bark, rarely on soil and granite; 1-3, 5-9 [O]; 21, 33.

TRAPELIOPSIS GRANUlOSA (Hoffm.) Lumbsch - on soil, rarely on wood; 6,8 [R]; 24, 27.

\# Tremella Cladoniae Diederich \& M. S. Christ. - on thalli of Cladonia spp. on logs and soil; $2,7,8[R]$.

\# Tremella hypogymniae Diederich \& M. S. Christ. - 6: $60^{\circ} 07^{\prime} 49.9^{\prime \prime} \mathrm{N}, 2^{\circ} 57^{\prime} 20.5^{\prime} \mathrm{E}$, pine forest with mosses and Vaccinium spp., on thallus of Hypogymnia physodes on bark of Betula sp., 19.05.2018, leg. DH, EK \& IS (BILAS) $\left[\mathrm{R}_{1}\right]$. New to $\mathrm{SPb}$, previously known from ELR and WLR (Kuznetsova et al., 2016; Himelbrant et al., 2018).

\# Tremella lichenicola Diederich - on thalli of Violella fucata on bark and wood; 2-9 [R].

\# TRICHONECTRIA ANisospora (Lowen) van den Boom \& Diederich - 3: 6004'16.0” N, $29^{\circ} 57^{\prime} 41.1$ 'E, pine-spruce forest with mosses, Vaccinium myrtillus, Oxalis acetosella, and Calamagrostis sp., on thallus of Hypogymnia physodes on bark of Pinus sylvestris, 28.04.2018, leg. DH \& IS (H) $\left[\mathrm{R}_{1}\right]$. New to $\mathrm{SPb}$, previously known from ELR (Stepanchikova et al., 2018).

TUCKERMANNOPSIS CHLOROPHYLLA (Willd. ex Humb.) Hale - on bark, wood, and granite; 1, 4-11, 13, 14, 16 [O]; 24, 29, 33, 38.

UMBILICARIA DEUSTA (L.) Baumg. - on granite; 8 $[\mathrm{R}] ; 21$.

$\dagger$ UsNea BARBata (L.) F. H. Wigg. - on bark of Acer sp., Betula sp., Picea abies, Populus spp., Sorbus aucuparia; 20 (H), 21 (Malysheva, 2003), 24 (Elenkin \& Beketov, 1919), 33 (Savicz, 1910).

Usnea DASOPOGa (Ach.) Nyl. - on bark of Acer sp., Alnus incana, Betula sp., Pinus sylvestris, Populus spp., and Sorbus aucuparia; 6, 9 [R]; 20, 37.

† UsNea Diplotypus Vain. - 38: on bark of Alnus glutinosa, 02.06.1938, leg. L. Fagerström (H 8003622).

† UsNEA FUlVOREAGENS (Räsänen) Räsänen - on bark of Populus balsamifera; 20 (Halonen et al., 1999; H 8003626).

USNEA HIRTA (L.) F. H. Wigg. - on bark, wood, and granite; 1, 2, 4, 6-11, 13, 14 [R]; 17, 18, 21, 23, 24, 29, 33, 37, 38.

USNEA SUBFLORIDANA Stirt. - on bark of Alnus glutinosa, Larix sp., Populus tremula, Quercus robur, Salix sp., and Tilia sp., worked timber; 1, 3, 4, 8, 9 [R]; 29, 34, 38.

$\dagger$ UsNea WASMUTHII Räsänen - on bark of Larix sp.; 34 (Stepanchikova et al., 2014).

VERRUCARIA BOBLEnSIS Servit - on calcareous stone; 1 (Pykälä et al., 2012) [ $\left.\mathrm{R}_{1}\right]$.

VERRUCARIA DOLOSA Hepp - on granite, concrete; $1,9[R]$.

VERRUCARIA MURALIS Ach. - on concrete; 1, 3, 9, $14,16[R]$. 
VERRUCARIA PILOSOIDES Servít - on concrete; 1, $8,9[R]$.

VERRUCARIA TECTORUM (A. Massal.) Körb. - 3: $60^{\circ} 04^{\prime} 28.7^{\prime \prime} \mathrm{N}, 29^{\circ} 57^{\prime} 32.8^{\prime \prime} \mathrm{E}$, concrete block near the road, on concrete, 28.04.2018, leg. $\mathrm{DH} \& \mathrm{IS}(\mathrm{H})\left[\mathrm{R}_{1}\right]$.

VERRUCARIA TORNENSIS H. Magn. - on concrete; 8 (Himelbrant et al., 2013) $\left[\mathrm{R}_{1}\right]$.

VERRUCARIA XYLOXENA Norman - on soil; 2, 9 [R]. VEZDAEA ACICULARIS Coppins - on soil; 8, 9 [R].

Vezdaea aestivalis (Ohlert) Tscherm.-Woess \& Poelt - 8: $60^{\circ} 12^{\prime} 02.6^{\prime \prime} \mathrm{N}, 29^{\circ} 34^{\prime} 57.5^{\prime \prime} \mathrm{E}$, path on a steep sandy slope, on soil and plant debris, 01.05.2016, leg. DH \& IS (LECB s. n.) $\left[R_{1}\right]$.

Violella fucata (Stirt.) T. Sprib. - on bark and wood; 1-9 [O].

VULPICIDA PINASTRI (Scop.) J.-E. Mattsson \& M. J. Lai - on bark and wood, rarely on granite and soil; $1-11,13,14,16[\mathrm{~F}] ; 17,20,21$, 24, 29, 33, 37, 38.

Xanthomendoza huculica (S. Y. Kondr.) Diederich

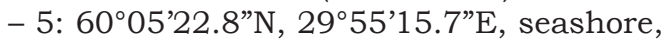
on bark of Quercus robur, 10.06.2018, leg. EK \& IS (LECB s. n.) [ $\left.R_{1}\right]$. New to Northwestern European Russia, known from the Republic of Mordovia (Urbanavichene \& Urbanavichus 2016). Distribution in Fennoscandia and Baltic countries: not reported. Sterile specimens are distinguished from the related taxa by typical labriform, crater-like to helm-shaped marginal soralia with true soredia, absence of blastidia, lobes becoming broader towards the ends, and corticolous habit (Wirth et al., 2013).

XANTHOPARMElia CONSPERSA (Ehrh. ex Ach.) Hale on granite; 2, 3, 6, 9, 11, 14 [R]; 20, 21, 24.

XANTHOPARMELIA PLITTII (Gyeln.) Hale - on granite; 1 (Stepanchikova et al., 2008) $\left[\mathrm{R}_{1}\right]$.

XANTHORIA PARIETINA (L.) Th. Fr. - on bark, wood, granite, slate, and concrete; 1-9, 11, 13, 14, 15, 16 [O]; 18, 21, 24, 27, 29, 33, 37, 38.

\# XeNonectriella lePtaleae (J. Steiner) Rossman

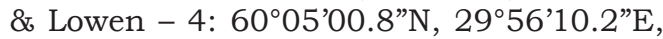
black alder-aspen forest with Filipendula ulmaria, on apothecia of Physcia aipolia on twigs of Populus tremula, 05.05.2018, leg. DH, EK \& IS (H) $\left[R_{1}\right]$.

Xylographa Parallela (Ach.: Fr.) Fr. - 8: $60^{\circ} 11^{\prime} 56.4^{\prime \prime} \mathrm{N}, 29^{\circ} 34^{\prime} 06.3$ " E, pine for est on slope, on wood of Pinus sylvestris, 01.05.2016, leg. DH \& IS (LECB s. n.) [ $\left.R_{1}\right]$.
XYlographa Vitiligo (Ach.) J. R. Laundon - 8: $60^{\circ} 11^{\prime} 56.4^{\prime \prime} \mathrm{N}, 29^{\circ} 34^{\prime} 06.3$ " E, pine for est on slope, on wood of Pinus sylvestris, 01.05.2016, leg. DH \& IS (LECB s. n.) [ $\left.R_{1}\right]$. New to $\mathrm{SPb}$, previously known from ELR and WLR (Kuznetsova et al., 2007; Himelbrant et al., 2018).

Xylopsora Caradocensis (Nyl.) Bendiksby \& Timdal - on wood, on bark of Alnus glutinosa, Picea abies, Pinus sylvestris, Quercus robur, 1-9 [R].

XYLOPSORA FRIESII (Ach.) Bendiksby \& Timdal - on bark and wood of conifers; 2, 3, 6-9 [R]; 34.

\section{Excluded and dubious taxa}

Acarospora macrospora (Hepp) A. Massal. ex Bagl. - reported by Malysheva $(1999,2003)$ from 14 (boulder), but the specimen was not found. The species is unknown in any other localities in $\mathrm{SPb}$ or LR. It is known to inhabit calcareous rocks (Nordin et al., 2011), hence its presence on a boulder in the study area (where all natural boulders are siliceous) is dubious.

Bacidia trachona (Ach.) Lettau - reported by Malysheva (1999) from 14 (boulder), but the specimen was not found and the species was not cited in later publication by the same author (Malysheva, 2003). No reliable records in $\mathrm{SPb}$ or $\mathrm{LR}$.

Bryoria implexa (Hoffm.) Brodo \& D. Hawksw. reported by different authors (Savicz, 1910; Elenkin \& Beketov, 1919; Fagerström, 1945; Malysheva, 1993, 2003; Malysheva et al., 1995) from 10-14, 16, 21, 23, 24, 38 (bark of conifers and Quercus robur). The specimens by L. Fagerström from 20 (H 8004175), by AE from 27 (LE s. n.), and by V. P. Savicz from 21 (LE s. n.) were re-identified as Bryoria capillaris, two specimens by O. A. Kataeva from 11 (LE s. n.) - as B. fuscescens; no more material was found in herbaria.

Calogaya lobulata (Flörke) Arup et al. - reported from 11 (Kataeva, 2002, 2004, as Caloplaca lobulata (Flörke) Hellb, bark of Alnus glutinosa). The specimen (LE L-4802) refers to Polycauliona polycarpa. The other record from 13 (Malysheva, 1993, 2003, as Xanthoria lobulata (Flk.) B. de Lesd., bark of Populus tremula) is not confirmed by herbarium specimens. No reliable records in $\mathrm{SPb}$ or LR. In Fennoscandia the species is known only in South Sweden (Nordin et al., 2011). 
Candelaria concolor (Dicks.) Stein - reported from 17, 24 (Elenkin, Beketov, 1919; bark of Pinus sylvestris, Populus tremula). No specimens found, no reliable records in $\mathrm{SPb}$ or LR. The record seems to be dubious and probably refers to Candelaria pacifica M. Westb. \& Arup, however it is impossible to state their identity when specimens are lacking.

!* Cetrelia olivetorum (Nyl.) W. L. Culb. \& C. F. Culb. - reported from 38 (Malysheva, 2005; city park, bark of Betula sp.). The specimens in LE refer to Platismatia glauca.

Chrysothrix chlorina (Ach.) J. R. Laundon - reported from 11 (Kataeva, 2002, 2004). The habitats and substrate (pine forests, bark of Pinus sylvestris) are not suitable for the species. No specimens found, no reliable records in $\mathrm{SPb}$. In LR it occurs on rocks or large boulders and rocks in the northern part of the Karelian Isthmus (Himelbrant et al., 2018; unpubl. data).

Cladonia coccifera (L.) Willd. - reported from 17, 24, 33 (Savicz, 1910; Elenkin \& Beketov, 1919; Malysheva, 2003). No specimens found. No reliable records in $\mathrm{SPb}$, very rare species in LR. All historical specimens from $\mathrm{SPb}$ and $\mathrm{LR}$ found in herbaria were re-identified as C. borealis and C. pleurota.

Cladonia gracilis (L.) Willd. subsp. elongata (Wulfen) Vain. - reported by Malysheva (2003) from 21. No specimens found, no reliable records in $\mathrm{SPb}$ or LR. Northern boreal and tundra lichen (Ahti, Stenroos, 2013).

Cladonia incrassata Flörke - reported by Malysheva (1999) from 14 (on stump). No specimens found, no reliable records in $\mathrm{SPb}$ or LR. Rare species, in Europe mostly inhabiting turf on disturbed peatbogs (Ahti, Stenroos, 2013).

Cladonia maxima (Asahina) Ahti - reported by Sokolova (1995) from 21. No specimens found, no reliable records in $\mathrm{SPb}$ or LR. Northern boreal and tundra species, common e. g. in Lapland (Ahti, Stenroos, 2013).

Cladonia peziziformis (With.) J. R. Laundon - reported by Merezhkovsky (1906, as C. leptophylla Flk.) from 33 (collected on wood). Rare species in Northern Europe, where it grows only on bare mineral soil (Ahti, Stenroos, 2013). Savicz (1910) already excluded this species for Repino based on morphological description.
Cladonia parasitica (Hoffm.) Hoffm. - reported by Sokolova (1995) from 12 and 16. No specimens found. The species is very rare in $\mathrm{SPb}$ and LR.

Cladonia portentosa (Dufour) Coem. - reported by Malysheva (2003) from 14, 21, and 27. No specimens found, no reliable records in $\mathrm{SPb}$ or LR. Oceanic species, in Finland known only on Baltic islands (Ahti \& Stenroos, 2013).

Cladonia ramulosa (With.) J. R. Laundon - reported from 11 (Kataeva, 2002, 2004). No specimens found, no reliable records in $\mathrm{SPb}$. The species occurs only in the westernmost part of LR on the islands in the Gulf of Finland (Alexeeva \& Himelbrant, 2007; Stepanchikova et al., 2019).

$\S$ Collema subnigrescens Degel. - cited by Malysheva (2003) for 34, but this erroneous citation refers to article on Cladonia macrophylla (Red..., 2000). No specimens found.

! Flavocetraria nivalis (L.) Kärnefelt \& A. Thell published by Savicz from 33 (Savicz, 1910, as Cetraria nivalis (L.) Ach.; LE L-10641, L-10642, L-10643) and cited by Malysheva (1999, 2003). Later, Fagerström reported this species from the vicinities of former settlement Tulokas, situated NE of Repino (Fagerström, 1940, 1945, as C. nivalis (L.) Ach.; H 8005016, 8005017). We assume that all published records correspond to the only locality between Repino and former Tulokas outside the study area. Our recent attempt to find $F$. nivalis in its historical locality was not successful; probably the population has disappeared (Red..., 2018).

Lecania prasinoides Elenkin - reported by Malysheva (1993, 2003) from 13 (bark of Betula sp.). No specimens found, no reliable records in $\mathrm{SPb}$ or LR. Besides that, this species inhabits bark which is sprayed with water or at least is very close to water.

Lecanora leptyrodes (Nyl.) G. B. F. Nilsson - reported by Fagerström (1945) from 33. The specimen refers to L. carpinea (H 8004310, sub Athallia pyracea).

Lepraria membranacea (Dicks.) Vain. - reported from 37 (Fagerström, 1945, as Physcia lanuginosa (Hoffm.) Vain.). No specimens found. The refered substrates - bark of Populus balsamifera and Acer sp. - are not suitable for the species; probably erroneous 
synonym was used by Fagerström for some Physciaceae).

Lobothallia alphoplaca (Wahlenb.) Hafellner reported by Malysheva $(1999,2003)$ from 14. No specimens found, no reliable records in $\mathrm{SPb}$ or LR. In Fennoscandia the species is known only from Norway (Nordin et al., 2011).

Loxospora elatina (Ach.) A. Massal. - reported by Malysheva (1993, as Lecanora chloropolia (Ericks.) Almb., bark of Salix sp.) from 13. No specimens found. The substrate is quite unusual for this sterile crustose species which prefers acid bark of conifers and birch. The only reliable record in $\mathrm{SPb}$ is in Gladyshevsky PA (Stepanchikova et al., 2014) outside the study area.

!* Melanelixia subargentifera (Nyl.) O. Blanco et al. - reported by Kataeva (2002, 2004, as Melanelia subargentifera (Nyl.) Essl.) from 11. The specimen (LE L-10614) refers to Tuckermannopsis chlorophylla.

Ochrolechia androgyna (Hoffm.) Arnold - reported from 1 (Stepanchikova et al., 2008). The specimen needs further investigation. No confirmed records of $O$. androgyna from $\mathrm{SPb}$ are known.

Parmelia saxatilis (L.) Ach. - reported by Fagerström (1945) from 18. No specimens found. The substrate (bark of Betula sp.) is inappropriate for the species; probably the material belonged to one of recently described corticolous Parmelia species, e. g. P. ernstiae Feuerer \& A. Thell.

Pertusaria leioplaca DC. - mentioned by Fagerström (1945) as Pertusaria sp.: "= P. leioplaca (Ach.) DC. var. clausa (Ach.) Erichs. ?” (29, bark of Sorbus aucuparia). No specimens found. The identification was originally published as doubtful.

Physcia leptalea (Ach.) DC. - reported by Fagerström (1945) from 20, 29, 33. The specimens (H 8005484, H 8005488, H 8000745) refer to $P$. adscendens and $P$. stellaris.

Physcia tribacia (Ach.) Nyl. - reported by Fagerström (1945) from 18 and 33. No specimens found, other historical records of this species from $\mathrm{SPb}$ mostly refer to $P$. dubia, sometimes to $P$. adscendens, or $P$. tenella. No reliable records in Fennoscandia (Nordin et al., 2011).

Placynthiella hyporhoda (Th. Fr.) Coppins \& P. James - reported by Elenkin (1912) from
17 as Saccomorpha arenicola Elenk.; also reported by Kataeva $(2002,2004)$ for 11. No specimens found. The type material of S. arenicola Elenkin (LE L-459!, L-460!) is morphologically and anatomically similar to Placynthiella uliginosa, hence the synonymization of this species with $P$. hyporhoda is questionable.

Ramalina calicaris (L.) Fr. - reported from 24 (Elenkin, Beketov, 1919). No specimens found, no reliable records in $\mathrm{SPb}$ or LR.

Usnea florida (L.) F. H. Wigg. - reported by Savicz (1910) from 33 (bark of Pinus sylvestris). No specimens found. The only reliable record of the species in LR refers to Luga District, where it is confined to broadleaved floodplain forest (Stepanchikova et al., 2018). All historical records from $\mathrm{SPb}$ and LR refer to other Usnea spp.

Xanthomendoza fallax (Hepp) Søchting et al. reported by Malysheva (1993, 1995, 2003, as Xanthoria fallax (Hepp) Arnold) from 10, 13,21 . No specimens found. All records from $\mathrm{SPb}$ and LR need revision.

Xanthoparmelia verruculifera (Nyl.) O. Blanco et al. - reported by Malysheva (1993, 2003, as Parmelia verruculifera Nyl., Neofuscelia verruculifera (Nyl.) Essl.) from 13. No specimens found. The substrate - bark of Populus tremula - is not suitable for the species.

\section{DISCUSSION}

The lichen biota of the northern shore of the Gulf of Finland in the limits of St. Petersburg counts 469 species (430 lichenized, 24 lichenicolous, 3 facultatively lichenicolous, and 12 non-lichenized saprobic fungi), of which 436 (93\%) were recorded in the period between 1993 and 2019. Altogether 48 species $(10 \%$ of the lichen biota) are new to $\mathrm{SPb}$, of them 2 (Lecidea malmeana and Micarea czarnotae) are new to Russia, 3 (Caloplaca lucifuga, Gyalecta nigricans, Micarea soralifera) are new to European Russia, 6 other (Agonimia flabelliformis, Endococcus verrucosus, Lecania turicensis, Micarea fallax, M. tomentosa, Xanthomendoza huculica) are new to Northwestern European Russia, and 3 further species (Lichenoconium lichenicola, Ramalina europaea, Sarcogyne hypophaea) are new to $\mathrm{SPb}$ and also not known from LR. Based on critical revision of the existing collections and publications from the period 1893-1979, 
we can list 191 species (or $41 \%$ of the whole recorded lichen diversity of the area), collected mostly before 1940. We have excluded 33 taxa from the lichen list of the study area as erroneous or dubious records. During thirteen years, 1980-1992, no any data about the lichen biota of this area could be obtained.

Nine key territories which we have explored (1-9, see Appendix 1) differ in their lichen diversity: 1 - 189 species, 2 - 191, 3 - 189, $4-121,5$ $-117,6-172,7-167,8-258,9-225$. The richest is lichen diversity of two territories that are located at the longest distance from the city (8 and 9). Typically, such genera as Bryoria, Cladonia, Imshaugia, Lecidea, Leptorhaphis, Palicella, Peltigera, etc. are better represented in remote territories (6-9). However, the richness of lichen species within the key territories reflects not only their position regards to the distance to the city, but also differences in size, landscape and history.

The contemporary lichen biota of the study area as a whole comprises 436 species, most of which are corticolous (276 species, 63\% of modern diversity) and lignicolous (136 species, 31\%). Saxicolous lichens are also quite diverse (114 species, 26\%), even though natural stony substrates are not abundant. The majority of saxicolous lichens ( 85 species) were found on granite boulders, and less than a half of the species (51) on concrete. Furthermore, concrete bore 22 species which were not found on other substrates; almost all of them are lichens confined to calcareous stones that are naturally absent in the study area. The lichen communities on soil (77 species, 18\%) are moderately poor for Karelian Isthmus, but very rich when compared to other territories within the city. Terricolous lichens are more diverse in distant areas $(6-34$ species, 7 $28,8-51,9-33$ ) and less numerous (between 0-18) closer to the city. Some lichens and allied fungi were recorded also on mosses (20 species), upturned roots (10 species), iron (9 species), fruit bodies of polypores (8 species), plant debris (7 species), resin of conifers (3 species), and epiphytic algae ( 2 species). Lichenicolous and facultatively lichenicolous fungi are represented by 26 species ( $6 \%$ of modern diversity).

The richest phorophytes in epiphytic lichens are Betula spp. (118 species), Quercus robur
(114 species), Alnus glutinosa (113 species), Sorbus aucuparia (110 species), Salix spp. (108 species), Pinus sylvestris (105 species), Populus tremula (104 species); moderately poor are Alnus incana (76 species), Acer platanoides and Picea abies (69 species each), Padus avium (67 species), Populus spp. along with P. tremula (66 species), Tilia spp. (62 species), Ulmus sp. (51 species), Fraxinus excelsior (41 species); other phorophytes were inhabited by 5-32 species.

Of 436 species forming the contemporary lichen biota, 429 species were collected by the authors of the present paper. Among them, 401 species were recorded within SA, and 28 were found only in the additional plots. An average amount of species per standard SA was $33.3 \pm 1.3$, with minimum 6 (2: in dark spruce forest with black alder near gas filling station and road in Lisy Nos), and maximum 95 species (9: in mixed deciduous forest in the floodplain of the Chernaya River far away from roads and settlements). Most lichens in the study area were rare [R] (246 species) or recorded only once $\left[R_{1}\right]$ (126 species), 40 species occurred occasionally [O], and 10 - frequently $[\mathrm{F}]$. Only six species were common [C], viz., Fuscidea pusilla, Lecanora pulicaris, L. symmicta, Parmelia sulcata, Parmeliopsis ambigua, and Scoliciosporum sarothamni, while one, Hypogymnia physodes, was very common.

One of the most significant parts of the studied lichen biota was found in pine forests, which are common throughout the study area. Altogether 242 species were recorded in pine forests $(56 \%$ of the contemporary lichen biota), of them 39 species were found only in this type of biotopes. The lichen diversity of pine forests significantly changes depending on the distance from the city of St. Petersburg. In the territories close to the city (1-6), an average number of species per SA in pine forests was $28.3 \pm 2.8$ (16 SA), whereas in the remote areas (7-9) this number was $45.6 \pm 3.7$ (12 SA). This reflects the impact of recreation: remote pine forests are less impacted by trampling than forests closer to the city, and therefore terricolous lichens are much more common and diverse there. However, epiphytic lichens were also more diverse in pine forests of the NW part of the study area: quite a number of typical taiga species like, e.g., Calicium glaucellum, C. pinastri, Lecanora norvegica, Lecidea leprarioides, Mycoblastus sanguinarius, 
and Ochrolechia microstictoides were recorded. In pine forests closer to the city, Lecanora conizaeoides occurred frequently, a species which is known to be tolerant to air pollution. Closer to the city, rowan undergrowth was often abundant in pine forests, which added such species as Anisomeridium polypori, Arthonia ruana, A. spadicea, Melanelixia glabratula, Physcia stellaris, etc.

Anthropogenic communities - wastelands, old concrete constructions, etc. - were inhabited by quite numerous lichens (207 species, 47\% of the lichen biota). Altogether 36 species were recorded exclusively in anthropogenic communities, they were mostly either saxicolous lichens on concrete (e.g., Flavoplaca spp., Myriolecis spp., Verrucaria spp.) or typical inhabitants of disturbed soils (like Enchylium tenax, Lemmopsis arnoldiana, Verrucaria xyloxena, Vezdaea aestivalis), and lichenicolous fungi.

It is noteworthy that anthropogenic tree stands, primarily historical parks (which include 300-year-old oaks planted at the time of Peter the Great near Sestroretsk and Lisy Nos), are very valuable sources for lichen diversity of the study area. Altogether 196 species (45\% of the lichen biota) were recorded in planted stands (parks, alleys and single trees), of them 28 species were recorded only in this group of communities, including red-listed Bacidia rubella, Bryoria furcellata, B. simplicior, Calicium viride, Chaenotheca phaeocephala, Inoderma byssaceum, Pertusaria coccodes, Ramalina baltica, and $R$. dilacerata (Red..., 2018).

Mixed coniferous-deciduous and deciduous (parvifoliate: birch, rowan, grey alder, willow etc.) forests are also quite rich with 192 species $(44 \%$ of the lichen biota). Black alder forests, which are nowadays the only forest community with natural dynamics within the study area, are also relatively rich in lichens (168 species, 39\%). However, they also bear sign of disturbance, and the specificity of the lichens of black alder forests is low (six species were found growing only in these communities). Relatively poor in lichens are birch forests (110 species, 25\% of the lichen biota), spruce forests (109 species, $25 \%$ ), grey alder forests (79 species, 18\%), willow brushwood (73 species, 17\%), peatbogs (68 species, 16\%), pine-spruce and spruce-pine forests (66 species, 15\%), as well as rare communities like aspen stands (99 species, 23\%), natural broadleaved stands (57 species, 13\%), and hazel stands (23 species, $5 \%$ ). Large granite boulders on open seashores and meadows are not very common in the investigated area, but their part in the studied lichen diversity is quite important (58 species, 13\%).

Forest communities on the northern shore of the Gulf of Finland in the limits of St. Petersburg are in general rather disturbed by loggings, fires, pollution, and recreation. Anyway, they are well-preserved compared to other city areas, and small areas of biologically valuable communities are still present here. In general, 29 indicator species and habitat specialists (Andersson et al., 2009) of lichens are known from the study area, but only 18 of them (12 indicators and 6 habitat specialists) were found recently, and other 11 species are known only from historical collections. It is noteworthy that nowadays, among all biotopes, the largest number of indicator species (nine, namely Arthonia helvola, Bacidia rubella, Chaenotheca brachypoda, C. hispidula, C. phaeocephala, Inoderma byssaceum, Pertusaria coccodes, and Ramalina baltica) occur in anthropogenic plant communities - mainly in historical parks (Dubki in Sestroretsk) and their remaining fragments (like "Blizhnie Dubki" within key territory 1 near Lisy Nos), alleys, or single old oaks on the seashore. Six indicator species were recorded in wet black alder forests, and also in mixed forests. Characteristically, in spruce forests only four indicator species (Arthonia helvola, A. spadicea, Chaenotheca brachypoda, and C. stemonea) were found. Meanwhile, in relatively old and undisturbed spruce forests in other territories within Karelian Isthmus, many indicator species and habitat specialists occur: e.g., 24 such species were recently recorded in spruce forests of Konevets Island (Himelbrant et al., 2018), and 17 are known from spruce forests of Smorodinka River valley (Stepanchikova et al., 2013).

Only 33 species (7\% of the revealed diversity) were not found in the last period of research. Of them few - Arthonia subfuscicola, Bacidia bagliettoana, Catinaria atropurpurea, Opegrapha vulgata, Peltigera ponojensis, and Thelocarpon laureri) - are small and/or hard to collect and distinguish from closely related and more com- 
mon species, while others - Biatora vernalis, Bryobilimbia hypnorum, Cliostomum griffithii, Lecanora albella, L. cateilea, and Mycobilimbia pilularis - are more or less easily recognized. All mentioned species, in our opinion, are rare in the region, but still can occur in the study area nowadays. However, we consider that the most part of the species that were not re-found (21 of 33), indeed have disappeared due to the loss of suitable habitats, increase of air pollution and pressure of recreation. Specialized and indicator species of biologically valuable forests are most sensitive to habitat transformation and pollution; of these, Bacidia fraxinea, B. polychroa, Chaenotheca subroscida, Chaenothecopsis viridialba, Icmadophila ericetorum, Leptogium saturninum, Nephroma parile, $N$. resupinatum, Ramalina thrausta, Schismatomma pericleum, and Scytinium lichenoides (Andersson et al., 2009) are known only from historical records. Terricolous lichens Cetraria aculeata, Cetrariella delisei, Peltigera leucophlebia, P. malacea, and $P$. neckeri are especially impacted by recreation, whereas corticolous Bryoria nadvornikiana, Usnea barbata, U. diplotypus, U. fulvoreagens, and $U$. wasmuthii are vulnerable to air pollution.

Altogether 44 species $(10 \%$ of the studied lichen biota) are red-listed in St. Petersburg (Red..., 2018), but 13 of them are known only from historical collections, including eight lichens qualified as Regionally Extinct (Bacidia fraxinea, B. polychroa, Cetrelia olivetorum, Chaenotheca subroscida, Leptogium saturninum, Nephroma resupinatum, Peltigera leucophlebia, Ramalina thrausta).

Thus, based on the lists of extinct indicator and red-listed species, it can be assumed that at the end of the 19th and beginning of the 20th century some undisturbed forests (probably their fragments) were still present within the study area. Nowadays the majority of natural forests are secondary there, and too young for a well-developed complex of indicator species. At the same time, some old-growth anthropogenic tree stands, inhabited by indicator species and habitat specialists nowadays, can be considered as biologically valuable. It can be assumed that in the future these communities may be a source of rare stenotopic lichens for restoring populations of such species also in the natural forests.
The lichen biota of the study area appears to be comparatively rich. It has lost only $7 \%$ of the recorded lichen diversity, however, most of these species are confined to biologically valuable forests (Andersson et al., 2009) and/ or they are red-listed (Red..., 2018). It could be assumed that the more significant part of the lichen biota (up to 150-170 species, taking into account existing general data on Isthmus karelicus) has disappeared from this long-time anthropogenized seashore territory, probably even before the start of lichen studies in the $19^{\text {th }}$ century. Although modern lichen diversity has been revealed quite comprehensively, as indirectly evidenced by data on the diversity of some genera such as Arthonia (13 species), Bacidina (7), Biatora (8), Lecania (7), Micarea (17), Thelocarpon (3), Verrucaria (7), as well as lichenicolous and facultatively lichenicolous fungi (27), the amount of indicator species in key groups nowadays is very low. Of 27 calicioid lichens and fungi which occur in the study area nowadays, only nine species are indicators or habitat specialists; of 13 species of Arthoniaonly two; of Bacidia - only one (three species in the past). Taking this into account, the modern lichen biota of the territory can be considered rich in comparison with other areas that are equally modified, but probably its diversity has been considerably reduced in the recent $100-150$ years.

Natural communities along with historical parks in NW part of St. Petersburg are important sources of biodiversity on regional level, and deserve protection. Fortunately, the most part of the studied area is represented by existing or proposed protected areas, and therefore has good potential for natural biota recovery.

\section{ACKNOWLEDGEMENTS}

The authors are grateful to the Directorate of Nature Protected Areas of St. Petersburg, as well as to V. N. Khramtsov and E. A. Volkova (Komarov Botanical Institute of RAS, St. Petersburg) for support in organization of field studies. We thank very much all participants of our field investigations in 2005-2017 for help and cooperation. We would like to thank Julia Gerasimova (Botanische Staatssammlung München) for identification of the specimen of Bacidina 
phacodes. We are deeply grateful to Teuvo Ahti (University of Helsinki) for important consultations during our work with herbarium materials and library of University of Helsinki. We appreciate the help of colleagues in $\mathrm{H}, \mathrm{S}, \mathrm{TU}$, TUR-V, and UPS during our work in herbaria. The study was supported by Russian Foundation for Basic Research (grant 20-04-00473) and carried out within the framework of the institutional research project "Flora of lichens and bryophytes of Russia and phytogeographically important regions" (no. AAAA-A19-119020690077-4) of the Komarov Botanical Institute of the Russian Academy of Sciences.

\section{REFERENCES}

Ābolina, A., Piterāns, A. \& Bambe, B. 2015. Lichens and bryophytes in Latvia. Checklist. Daugavpils, Daugavpils Universitātes Akadēmiskais apgāds "Saule». 213 pp. (In Latvian, English introduction).

Ahlner, S. 1948. Utbredningstyper bland nordiska barrträdslavar. Acta Phytogeographica Suecica 22: 1-257.

Ahti T. \& Stenroos S. 2013. Cladonia. In: Ahti, T., Stenroos, S. \& Moberg, R. (eds). Nordic Lichen Flora. Volume 5. Cladoniaceae. Nordic Lichen Society, Göteborg. Pp. 8-86.

Ahti T. 1966. Parmelia olivacea and the allied nonisidiate and non-sorediate corticolous lichens in the Northern Hemisphere. Acta Botanica Fennica 70: $1-68$.

Alexeeva, N. M. \& Himelbrant, D. E. 2007. Lichens. In: Volkova, E. A., Glazkova, E. A., Isachenko, G. A. \& Khramtsov, G. A. (eds). Environment and biological diversity of Berezovye Islands Archipelago (The Gulf of Finland). St. Petersburg, pp. 213-229. (In Russian, English summary).

Andersson, L., Alexeeva, N. M. \& Kuznetsova, E. S. (eds.). 2009. Survey of biologically valuable forests in Northwestern European Russia. Vol. 2. Identification manual of species to be used during survey at stand level. St. Petersburg. 258 pp. (In Russian).

Czarnota, P. 2007. The lichen genus Micarea (Lecanorales, Ascomycota) in Poland. Polish Botanical Studies 23: 1-199.

Czernyadjeva, I. V., Afonina, O. M., Ageev, D. V., Baisheva, E. Z., Bulyonkova, T. M., Cherenkova, N. N., Doroshina, G. Ya., Drovnina, S. I., Dugarova, O. D., Dulepova, N. A., Dyachenko, A. P., Filippova, N. V., Ginzburg, E. G., Gogorev, R. M., Himelbrant, D. E., Ignatov, M. S., Kataeva, O. A., Kotkova, V. M., Kuragina, N. S., Kurbatova, L. E., Kushnevskaya, E. V., Kuzmina, E. Yu., Melekhin, A. V., Notov, A. A., Novozhilov, Yu. K., Popov, S. Yu., Popova, N. N., Potemkin, A. D., Stepanchikova, I. S., Stepanova, V. A., Tubanova,
D. Ya., Vlasenko, A. V., Vlasenko, V. A., Voronova, O. G. \& Zhalov, Kh. Kh. 2019. New cryptogamic records. 4. Novosti sistematiki nizshikh rastenii 53(2): 431-479. https://doi.org/10.31111/ nsnr/2019.53.2.431

Diederich, P. Lawrey, J. D. \& Ertz, D. 2018. The 2018 classification and checklist of lichenicolous fungi, with 2000 non-lichenized, obligately lichenicolous taxa. PLoS ONE 121: 340-426. https://doi. org/10.1639/0007-2745-121.3.340

Dubyansky, V. A. 1910. Dune excursion. The essay of the Sestroretsk Dunes and their vegetation. Pedagogichesky ezhegodnik lesnogo kommercheskogo uchilishcha II: 83-112 (In Russian).

Dubyansky, V. A. 1919. Dune excursion. The essay of the Sestroretsk Dunes and their vegetation ( $2^{\text {nd }}$ ed.). St. Petersburg. Petrograd. 31 pp. (In Russian).

Elenkin, A. A. \& Beketov, I. A. 1919. Fourteen sporological excursiones in vicinities of Primorskaya railway from station Lakhta to station Duny, undertaken in 1918. Izvestiya Glavnogo Botanicheskogo Sada RSFSR 19(1): 1-9. (In Russian).

Elenkin, A. A. \& Petrov, V. A. 1919. About some lichens rare in Petrograd Gouvernior. Izvestiya Glavnogo Botanicheskogo Sada RSFSR 19(1): 15-20. (In Russian).

Elenkin, A. A. 1901. Lichenes florae Rossiae et regionum confinium orientalium. Fasciculus I. Acta Horti Petropolitanae 19(1): 1-52.

Elenkin, A. A. 1904. Lichenes florae Rossiae et regionum confinium orientalium. Fasciculus II-IV. Acta Horti Petropolitanae 24(1): 1-118.

Elenkin, A. A. 1912. About the lichen Saccomorpha arenicola mihi from new genus (Saccomorpha mihi) and new family (Saccomorphaceae mihi). Trudy presnovodnoy biologicheskoy stantsii Imperatorskogo Sankt-Peterburgskogo obschestva estestvoispytateley 3: 174-212. (In Russian).

Fadeeva, M. A., Golubkova, N. S., Vitikainen, O. \& Ahti, T. 2007. Conspectus of lichens and lichenicolous fungi of the Republic of Karelia. Karelian Research Centre RAS, Petrozavodsk. 194 pp. (In Russian, English summary).

Fagerström, L. 1940. Cetraria nivalis (L.) Ach. funnen i Terijoki. Memoranda Societatis pro Fauna et Flora Fennica 15: 23-25.

Fagerström, L. 1945. Ett bidrag till kännedomen om lavfloran i Terijoki socken på Karelska näset. Memoranda Societatis pro Fauna et Flora Fennica 20: $155-170$.

Fletcher, A., James, P. W \& Purvis, O. W. 2009. Lecania A. Massal. (1853). In: Smith, C. W., Aptroot, A., Coppins, B. J., Fletcher, A., Gilbert, O. L., James, P. W. \& Wolseley, P. A. (eds). The lichen flora of Great Britain and Ireland. London, British Lichen Society. Pp. 454-463.

Foucard, T. 2001. Svenska skorplavar och svampar som växer på dem. Stockholm. 392 pp.

Gagarina, L. V. 2017. Family Gyalectaceae. In: Andreev, M. P. \& Himelbrant, D. E. (eds). The lichen flora 
of Russia. Moscow, St. Petersburg. Pp. 31-65. (In Russian).

Gagarina, L. V., Konoreva, L. A., 2015. The revision of the Micarea Fr. in the herbarium of the laboratory of lichenology and bryology of the Komarov Botanical Institute, RAS (LE). Vestnik Tverskogo gosudarstvennogo universiteta. Seriya „Biologia $i$ ekologiya" 3: 154-165. (In Russian).

Gasparyan, A., Sipman, H. \& Lucking, R. 2017. Ramalina europaea and $R$. labiosorediata, two new species of the $R$. pollinaria group (Ascomycota: Ramalinaceae), and two new typifications for $\mathrm{Li}$ chen pollinarius and $L$. squarrosus. The Lichenologist 49(4): 301-319. https://doi.org/10.1017/ S0024282917000226

Guzow-Krzemińska, B., Czarnota, P., Łubek, A. \& Kukwa, M. 2016. Micarea soralifera sp. nov., a new sorediate species in the $M$. prasina group. The Lichenologist 48(3): 161-169. https://doi. org/10.1017/S0024282916000050

Guzow-Krzemińska, B., Halda, J. P. \& Czarnota, P. 2012. A new Agonimia from Europe with a flabelliform thallus. Lichenologist 44(1): 55-66. https:/ / doi.org/10.1017/S0024282911000600

Hafellner, J. \& Türk, R. 2016. Die lichenisierten Pilze Österreichs - eine neue Checkliste der bisher nachgewiesenen Taxa mit Angaben zur Verbreitung und Substratökologie. Stapfia 104(1): 1-216.

Hafellner, J. 1994. Beiträge zu einem Prodromus der lichenicolen Pilze Österreichs und angrenzender Gebiete. I. Einige neue oder seltene Arten. Herzogia 10: 1-28.

Hakulinen, R. 1962a. Die Flechtengattung Anaptychia Körb. in Ostfennoskandien. Archivum Societatis Zoologicae-Botanicae Fennicae „Vanamo“ 17(3): 121-133.

Hakulinen, R. 1962b. Über die Verbreitung einiger Cetraria Arten in Ostfennoskandien. Archivum Societatis Zoologicae-Botanicae Fennicae ,Vanamo“ 17(3): 138-149.

Halonen, P., Myllys, L., Ahti, T. \& Petrova, O. V. 1999. The lichen genus Usnea in eastern Fennoscandia. III. The shrubby species. Annales Botanici Fennici 36(4): 235-256.

Harris, R. 1995. More Florida Lichens: Including the $10 \phi$ Tour of the Pyrenolichens. Published by the author. $192 \mathrm{pp}$.

Hawksworth, D. L. 1977. Taxonomic and biological observations on the genus Lichenoconium (Sphaeropsidales). Persoonia 9: 159-198.

Himelbrant, D. E. \& Andersson, L. 2008. Lichens of biologically valuable territory Kurgal'sky Peninsula, Leningrad Region. In: XVII Symposium of the Baltic Mycologists and Lichenologists. Estonia, Saaremaa, Mändjala, 17-21 September 2008. Abstracts. Tartu. Pp. 19-20.

Himelbrant, D. E., Motiejūnaite, J., Pykälä, J., Schiefelbein, U. \& Stepanchikova, I. S. 2013. New records of lichens and allied fungi from the Leningrad Re- gion, Russia. IV. Folia Cryptogamica Estonica 50: 23-31. https:/ / doi.org/10.12697/fce.2013.50.04

Himelbrant, D. E., Motiejūnaitè, J., Stepanchikova, I. S. \& Tagirdzhanova, G. M. 2014. New records of lichens and allied fungi from the Leningrad Region, Russia. V. Folia Cryptogamica Estonica 51: 49-55. https://doi.org/10.12697/fce.2014.51.04

Himelbrant, D. E., Stepanchikova, I. S., Kuznetsova, E. S., Motiejūnaitė, J. \& Konoreva, L. A. 2018. Konevets Island (Leningrad Region, Russia) - a historical refuge of lichen diversity in Lake Ladoga. Folia Cryptogamica Estonica 55: 51-78. https:// doi.org/10.12697/fce.2018.55.07

Himelbrant, D. E., Stepanchikova, I. S., Motiejūnaitè, J., Gerasimova, J. V., Kuznetsova, E. S., Dyomina, A. V. \& Tsurykau, A. G. 2017. New records of lichens and allied fungi from the Leningrad Region, Russia. VIII. Folia Cryptogamica Estonica 54: 63-70. https:/ / doi.org/10.12697/fce.2017.54.11

Himelbrant, D. E., Stepanchikova, I. S., Motiejūnaitè, J., Kuznetsova, E. S., Tagirdzhanova, G. \& Frolov, I. V. 2019. New records of lichens and allied fungi from the Leningrad Region, Russia. X. Folia Cryptogamica Estonica 56: 23-29. https://doi. org/10.12697/fce.2019.56.04

Himelbrant, D. E., Stepanchikova, I. S., Motiejūnaite, J., Vondrak, J., Tagirdzhanova, G. M., Gagarina, L. V. \& Kuznetsova, E. S. 2015. New records of lichens and allied fungi from the Leningrad Region, Russia. VI. Folia Cryptogamica Estonica 52: 21-28. https:/ / doi.org/ 10.12697/fce.2015.52.03

Isachenko, G. A. 1998. Window to the Europe: history and landscapes. St. Petersburg. 474 pp. (In Russian)

Kataeva, O. A. 2002. Lichens. In: E. A., Volkova, G. A., Isachenko \& V. N., Khramtsov (eds). The Protected Area Komarovsky Bereg. St. Petersburg. Pp. 39-43. (In Russian)

Kataeva, O. A. 2004. Lichens. In: E. A., Volkova, G. A., Isachenko \& V. N., Khramtsov (eds). The Protected Area Komarovsky Bereg (2 ${ }^{\text {nd }}$ ed.). St. Petersburg. Pp. 39-43. (In Russian).

Khramtsov V. N., Kovaleva T. V. \& Natsvaladze N. Yu. (eds). 2016. Atlas of protected areas of St. Petersburg (II edition). Marafon, St. Petersburg. 176 pp.

Kocourková, J. \& Boom, P. P. G. van den 2005. Lichenicolous fungi from the Czech Republic II. Arthrorhaphis arctoparmeliae sp. nov. and some new records for the country. Herzogia 18: 23-35.

Konoreva, L., Chesnokov, S., Kuznetsova, E. \& Stepanchikova, I. 2019. Remarkable records of Micarea from the Russian Far East and significant extension of Micarea laeta and M. microareolata range. Botanica 25(2): 186-201. DOI: https://doi. org/ 10.2478/botlit-2019-0020

Kotiranta, H., Uotila, P., Sulkava, S. \& Peltonen, S.-L. (eds). 1998. Red Data Book of East Fennoscandia. Helsinki. 351 pp.

Kukwa, M. 2011. The lichen genus Ochrolechia in Europe. Gdańsk. 309 pp. 
Kuznetsova, E. S., Kataeva, O. A., Himelbrant, D. E. \& Motiejūnaitè, J. 2016. Lichens and allied fungi of the Ragusha River Protected Area (Leningrad Region, Russia). Folia Cryptogamica Estonica 53: 71-80. https://doi.org/10.12697/fce.2016.53.09

Kuznetsova, E., Ahti, T. \& Himelbrant, D. 2007. Lichens and allied fungi of the Eastern Leningrad Region. Norrlinia 16: 1-62.

Launis, A., Malíček, J., Svensson, M., Tsurykau, A., Sérusiaux, E. \& Myllys, L. 2019a. Sharpening species boundaries in the Micarea prasina group, with a new circumscription of the type species $M$. prasina. Mycologia 111: 574-592. https://doi.org/ 10.1080/00275514.2019.1603044

Launis, A., Pykälä, J., van den Boom, P., Sérusiaux, E. \& Myllys, L. 2019b. Four new epiphytic species in the Micarea prasina group from Europe. Lichenologist 51: 7-25. https://doi.org/10.1017/ S0024282918000555

Lawrey, J. D. \& Diederich, P. 2018. Lichenicolous fungi - worldwide checklist, including isolated cultures and sequences available. http://www.lichenicolous.net (25 March 2019).

Lemberg, B. 1933. Über die Vegetation der Flugsandgebiete an den Küsten Finnlands. I. Die Sukzession. Acta Botanica Fennica 12: 1-143.

Lemberg, B. 1935. Über die Vegetation der Flugsandgebiete an den Küsten Finnlands. III. Die einzelnen Flugsangebiete. Acta Botanica Fennica 14: 1-75.

Malme, G. O. A. 1895. Lichenologiska notiser. IV. Adjumenta av lichenographiam Sueciae meridionalis. Botaniska notiser. Pp. 207-213.

Malysheva, N. V. 1993. The lichens of the Leningrad vicinities. 1. Changes in the lichen diversity in vicinities of the O'lgino railway station (Leningrad Region) for the 72 years. Novitates Systematicae Plantarum Non Vascularium 29: 119-124. (In Russian).

Malysheva, N. V. 1999. The lichens of the St. Petersburg vicinities. 4. Current state and changes in the lichen diversity in the Repino (former Kuokkala) and vicinities for the 90 years. Novitates Systematicae Plantarum Non Vascularium 33: 142-153. (In Russian).

Malysheva, N. V. 2003. The lichens of the St. Petersburg. Trudy Sankt-Petersburgskogo obschestva estestvoispytateley. Series 3 79: 1-100. (In Russian).

Malysheva, N. V. 2005. The lichens of the St. Petersburg vicinities. 7. The lichens of the Zelenogorsk. Novitates Systematicae Plantarum Non Vascularium 39: 213-219. (In Russian).

Malysheva, N. V., Nikolaev, P. M., Neshataev, V. Yu., Reyman, A. L. \& Vlasov, D. Yu. 1995. Foundation history and current state of Dubki Park in Sestroretsk (on the base of lichenological, phytopathological and phytosociological analyses). Vestnik Sankt-Petersburgskogo Universiteta, series 3 2(10): 46-51. (In Russian).

Mereschkowsky, K. 1913. Lichenes Rossiae exsiccatos. Fasculus I-III. Kazan'. 47 pp.
Mereschkowsky, K. S. 1906. To the lichens of the Russian North. Protokoly zasedany obschestva estestvoispytateley pri Imperatorskom Kazanskom universitete. Prilozhenie 234: 1-15. (In Russian).

Moiseeva, E. N. 1959. To the localization of enzymes and lichen acids in the lichen thalli. Botanicheskii Zhurnal 44(8): 1128-1134. (In Russian).

Moiseeva, E. N. 1961. Biochemical properties and applied value of lichens. Moscow, Leningrad. 66 pp. (In Russian).

Motiejūnaitè, J., 2017. Supplemented checklist of lichens and allied fungi of Lithuania. Botanica Lithuanica 23(2): 89-106. https://doi.org/10.1515/ botlit-2017-0011

Muchnik, E., Konoreva, L., Chesnokov, S., Paukov, A., Tsurykau, A. \& Gerasimova, J. 2019. New and otherwise noteworthy records of lichenized and lichenicolous fungi from central European Russia. Herzogia 32: 111-126. https://doi. org/10.13158/heia.32.1.2019.111

Nimis, P. L., Hafellner, J., Roux, C., Clerc, P., Mayrhofer, H., Martellos, S. \& Bilovitz, P. O. 2018. The lichens of the Alps - an annotated checklist. MycoKeys 31: 1-634. https://doi.org/10.3897/ mycokeys.31.23568

Nordin, A., Moberg, R., Tønsberg, T., Vitikainen, O., Dalsätt, Å., Myrdal, M., Snitting, D. \& Ekman, S. 2011. Santesson's Checklist of Fennoscandian Lichen-forming and Lichenicolous Fungi. Ver. April 29, 2011 http://130.238.83.220/santesson/ home.php (30 March 2020).

Notov, A. A., Himelbrant, D. E. \& Stepanchikova, I. S. 2019. New records of lichens and lichenicolous fungi from the Tver Region. Novosti sistematiki nizshikh rastenii 53(1): 157-166. https://doi. org/10.311/nsnr/2019.53.1.157

Notov, A. A., Himelbrant, D. E. \& Urbanavichus, G. P. 2011. Annotated list of the lichen flora of the Tver' Region. Tver'. 124 pp. (In Russian, English abstract).

Orange, A., James, P. W. \& White, F. J. 2001. Microchemical methods for the identification of lichens. London. $101 \mathrm{pp}$.

Pykälä, J., Stepanchikova, I. S., Himelbrant, D. E., Kuznetsova, E. S. \& Alexeeva, N. M. 2012. The lichen genera Thelidium and Verrucaria in the Leningrad Region (Russia). Folia Cryptogamica Estonica 49: 45-57.

Randlane, T., Saag, A. \& Suija, A. 2019. Lichenized, lichenicolous and allied fungi of Estonia. Ver. December 31, 2019 - http://esamba.bo.bg.ut.ee/ checklist/est/home.php (25 March 2020).

Red Data Book of Nature of the Leningrad Region. Vol. 2. Plants and Fungi. 2000. St. Petersburg. 672 pp. (In Russian).

Red Data Book of St. Petersburg. 2018. St. Petersburg. 568 pp. (In Russian).

Savicz, V. P. 1910. The lichens collected in Kuokkala vicinities (Vyborg Gouvernior) in 1907 by N. N. Voronikhin. Trudy studen'cheskikh nauchnykh 
kruzhkov fiziko-matematicheskogo fakul'teta Sankt-Petersburgskogo Universiteta 2: 11-16. (In Russian).

Savicz, V. P. 1921. New lichens to the Petrograd Gouvernior. Izvestiya Glavnogo Botanicheskogo Sada RSFSR 20: 23-24. (In Russian).

Savicz, V. P. 1972. Lichenotheca Rossica. Regionibus confinibus completa. Decas XXI. Novitates Systematicae Plantarum Non Vascularium 9: 249-252. (In Russian).

Sokolova, S. V. 1995. The genus Cladonia in the Leningrad Region. Novitates Systematicae Plantarum Non Vascularium 30: 90-93. (In Russian).

Stepanchikova, I. S., Andreev, M. P., Himelbrant, D. E., Motiejūnaitè, J., Schiefelbein, U., Konoreva, L. A. \& Ahti, T. 2017a. The lichens of Bolshoy Tuters Island (Tytärsaari), Leningrad Region, Russia. Folia Cryptogamica Estonica 54: 95-116. https:/ / doi.org/10.12697/fce.2017.54.14

Stepanchikova, I. S., Himelbrant, D. E. \& Konoreva, L. A. 2008. Lichens of Severo-Primorsky Park in St. Petersburg. Vestnik Sankt-Peterburgskogo Gosudarstvennogo Universiteta. Series 3 (Biology): 55-66. (In Russian, English summary). https:// doi.org/10.31111/nsnr/2014.48.291

Stepanchikova, I. S., Himelbrant, D. E. \& Konoreva, L. A. 2014. The lichens and allied fungi of the Gladyshevsky Protected Area (Saint Petersburg). Novitates Systematicae Plantarum Non Vascularium 48: 291-314.

Stepanchikova, I. S., Himelbrant, D. E. \& Kuznetsova, E. S. 2017b. Lichens. In: Volkova, E. A., Isachenko, G. A., Khramtsov, V. N. (eds). The nature of the Protected Area "Ozero Schuch'e”. St. Petersburg, pp. 97-113. (In Russian, English summary).

Stepanchikova, I. S., Himelbrant, D. E., Kukwa, M. \& Kuznetsova, E. S. 2010a. Additions to the lichen diversity of the protected areas of the Finnish Gulf shore (in the limits of St. Petersburg). Novitates Systematicae Plantarum Non Vascularium 44: 237-244. (In Russian, English abstract).

Stepanchikova, I. S., Himelbrant, D. E., Motiejūnaitė, J., Ahti, T., Suija, A., Kuznetsova, E. S. \& Dyomina, A. V. 2018. New records of lichens and allied fungi from the Leningrad Region, Russia. IX. Folia Cryptogamica Estonica 55: 117-124. https:/ / doi. org/10.12697/fce.2018.55.12

Stepanchikova, I. S., Himelbrant, D. E., Schiefelbein, U., Motiejūnaite, J., Ahti, T. \& Andreev, M. P. 2019. The lichens of Moshchny Island (Lavansaari) - one of the remote islands in the Gulf of Finland. Folia Cryptogamica Estonica 56: 31-52. https://doi. org/10.12697/fce.2019.56.05

Stepanchikova, I. S., Kukwa, M., Kuznetsova, E. S., Motiejūnaitè, J. \& Himelbrant, D. E. 2010b. New records of lichens and allied fungi from the Leningrad Region, Russia. Folia Cryptogamica Estonica: 47: 77-84.

Stepanchikova, I. S., Tagirdzhanova, G. M. \& Himelbrant, D. E. 2013. The lichens and allied fungi of the Smorodinka River valley (Leningrad Region). Novitates Systematicae Plantarum Non Vascularium 47: 262-278. https://doi.org/10.31111/ nsnr/2013.47.262

Tarasova, V. N., Konoreva, L. A., Zhurbenko, M. P., Pystina, T. N., Chesnokov, S. V., Androsova, V. I., Sonina, A. V., Semenova, N. A. \& Valekzhanin, A. A. 2020. New and rare species of lichens and allied fungi from Arkhangelsk Region (NW Russia). Folia Cryptogamica Estonica 57: 85-100.

Thor, G. 1988. Caloplaca lucifuga: a new lichen species from Europe. The Lichenologist 20(2): 175-178. https:/ / doi.org/ 10.1017/S0024282988000180

Urbanavichene, I. N. \& Urbanavichus, G. P. 2016. The lichen flora of the Mordovsky Reserve (an annotated species list). Flora and fauna of reserves 126: 1-41. (In Russian).

Urbanavichus, G. P. \& Urbanavichene, I. N. 2017. Contribution to the lichen flora of Erzi Nature Reserve, Republic of Ingushetia, North Caucasus, Russia. Willdenowia 47(3): 227-236. https: / / doi. org/10.3372/wi.47.47306

Vainio, E. A. 1878. Lichenes in viciniis Viburgi observati. Meddelanden af Societas pro Fauna et Flora Fennica 2: 35-72.

Vainio, E. A. 1921. Lichenographia Fennica I Pyrenolichens iisque proximi Pyrenomycets et Lichens imperfecti. Acta Societatis Pro Fauna et Flora Fennica 49(2): 1-274.

Vereitinov, I. A. 1906. Short remarks on the variability of Parmelia physodes (L.) Ach. Izvestiya Imperatorskogo Botanicheskogo Sada 6(4): 128-132. (In Russian).

Vereitinov, I. A., Kashmensky, B. O. 1907. School herbarium of the cryptogamic plants. Issue 1. List of lichens. Yur'ev. 7 pp. (In Russian).

Vitikainen, O. 1968. On the sorediate species of the lichen genus Physconia Poelt in Eastern Fennoscandia. Annales Botanici Fennici 5: 1-9.

Vitikainen, O. 1994. Taxonomic revision of Peltigera (lichenized Ascomycotina) in Europe. Acta Botnici Fennici 152: 1-96.

Vondrák, J., Ismailov, A. \& Urbanavichus, G. 2017. Lichens of the family Teloschistaceae in Dagestan, an eastern part of the Caucasian biodiversity hotspot. Nova Hedwigia 104: 483-498. https://doi. org/10.1127/nova_hedwigia/2016/0387

Vondrák, J., Redchenko, O., Himelbrant, D., Stepanchikova, I. \& Kuznetsova, E. 2010. Some sterile Caloplaca crusts identified by molecular data from the Leningrad region (Russia). Folia Cryptogamica Estonica 47: 97-99.

Wirth, V., Hauck, M. \& Schultz, M. 2013. Die Flechten Deutschlands. Band 1. Eugen Ulmer, Stuttgart. 672 pp.

Zhurbenko, M. P. \& Notov, A. A. 2015. Lichenicolous lichen Placocarpus americanus and some noteworthy lichenicolous fungi from Russia. Folia Cryptogamica Estonica 52: 95-99. https://doi. org/ 10.12697/fce.2015.52.12 


\section{Appendix. List of the studied territories in St. Petersburg}

Area Name, description, geographical coordinates, diversity of biotopes, collectors, herbaria, references

Years

Recently studied territories (1993 and later)

Key territories intensively studied by the authors

$1 \quad$ Primorsky District, S and SW of Ol'gino, Severnoe Poberezhie Nevskoy Guby PA (former Severo-Primorsky Park), 5959'33.8”-6000'17.0”N, 3000'37.7”-05'57.0”E. 29 SA, 22 AP. Mostly deciduous and mixed forests, often with broadleaved trees, pine stands, and remains of old park: aspen-pine, birch, birch-pine-spruce, pine-birch, black alder, grey alder, black alder-birch-aspen, ash-oak-black alder forests; ash, aspen, birch, poplar, and willow stands, groups and alleys of old oaks, lindens, maples, and horse-chestnuts; seashore communities; granite boulders; concrete constructions and other anthropogenic habitats. IS, LK, DH, EK, AD (H, LE, LECB; Stepanchikova et al., 2008, 2010a; Pykälä et al., 2012; Himelbrant et al., 2017; Red..., 2018).

2 Primorsky District, S and SW of Lisy Nos, Lisy Nos Proposed PA, 6000'35.3"-01'59.2”N, 2957'50.8”59’38.3”E. 21 SA, 7 AP. Mostly wet black alder communities: swampy birch-black alder and black alder forests, birch, pine, spruce, and black alder-spruce forests; maple-black alder, willow, and young aspen seashore and inland stands, aspen stands, planted broadleaved trees; granite boulders; meadows, anthropogenic wastelands, ruins of buildings. DH, EK, IS (BILAS, H, LECB).

3 Kurortny District, SE part of Sestroretsk, Tarkhovka Proposed PA (Tarkhovka Park), 6003'38.0"-04'42.7”N, 2956'03.5"-58'09.6”'E. 16 SA, 9 AP. Mostly secondary forests: swampy and seashore black alder forests; pine, pine-spruce, spruce-black alder, birch, birch-pine-spruce forests; aspen and willow stands, maple and larch alleys, old pines and oaks on seashore, groups of ashes and horse-chestnuts; granite boulders; glades, concrete constructions, and other anthropogenic habitats. DH, IS, EK (BILAS, H, LECB).

4 Kurortny District, S part of Sestroretsk, Gagarka Proposed PA, 6004'43.6”-05'14.9”N, 2955'53.9”57'00.1"E. 11 SA, 2 AP. Mostly secondary forests: swampy or drained seashore and inland black alder forests, seashore willow-black alder shrubs, swampy willow shrubs, pine forests, black alder-birch-aspen and pine-black alder-birch forests; concrete constructions in town park. EK, DH, IS (H, LECB).

5 Kurortny District, Sestroretsk, Dubki Park (former park Dal'nie Dubki, old oaks planted in 1717), $60^{\circ} 05^{\prime} 15.3{ }^{\prime}-31.2$ ” N $29^{\circ} 55^{\prime} 14.8^{\prime}-5632.0^{\prime}$ E. 9 SA, 7 AP. Historical park: old oaks, lindens, and poplars, oak-birch and oak stands, alleys of broadleaved trees; seashore and inland black alder stands, pine-birch forests with undergrowth; military pillbox and other anthropogenic constructions. EK, DH, IS, LG (BILAS, H, LECB; Himelbrant et al., 2014; Red..., 2018)

$6 \quad$ Kurortny District, Ik, former Finnish socken Terijoki, N part of Sestroretsk and E part of Solnechnoe (Ollila), Sestroretskye Duny Proposed PA, 6005'15.2”-08'44.4”N, 2956'01.3”-58'45.0”E. 20 SA, 3 AP. Mostly secondary coniferous forests: seashore and inland pine forests, black alder, grey alder, black alder-birch, birchpine, birch-spruce, birch, and coniferous-broadleaved forests; swampy pine forests and peatbogs; seashore communities; anthropogenic habitats. IS, EK, DH (BILAS, H, LECB).

7 Kurortny District, Ik, former Finnish socken Terijoki, Komarovo (Kellomäki), Komarovsky Bereg PA, $60^{\circ} 10^{\prime} 44^{\prime \prime}-11^{\prime} 17^{\prime \prime} \mathrm{N}, 29^{\circ} 45^{\prime} 49^{\prime \prime}-47^{\prime} 50$ ”'E. 8 SA, 4 AP. Mostly secondary, but relatively old and undisturbed forests: seashore and inland pine forests on sand, spruce, birch-spruce, birch and wet spruce-black alder forests; anthropogenic habitats. DH, EK, IS, GT, AD, ER (LECB; Stepanchikova et al., 2010b; Kukwa, 2011; Red..., 2018).

8 Kurortny District, Ik, former Finnish socken Uusikirkko, Serovo (Vammelsuu) and Ushkovo (Tyrisevä), Beregovoy Ustup Serovo Proposed PA, 60¹1'48.2”-13’09.0”N, 29³6’35.0”-37’33.0”E. 21 SA, 20 AP. Different biotopes, mostly coniferous forests: pine, pine-birch, spruce, spruce-pine, spruce-aspen-birch, swampy black alder, and floodplain deciduous forests; swampy pine forests; hazel community in the stream valley; old oak and poplar alleys, planted larch stand; granite boulders; old military constructions (granite and concrete), other anthropogenic habitats. EK, IS, DH (BILAS, H, LE, LECB; Pykälä et al., 2012; Himelbrant et al., 2013; Red..., 2018).

9 Kurortny District, Ik, former Finnish socken Uusikirkko, S part of Gladyshevsky PA, 60¹1'39.3”-12'41.5”N, 2931'34.7"-33'11.0”E. 20 SA, 1 AP. Mostly secondary, but relatively undisturbed forests: birch, birch-aspen, birch-pine, black alder (seashore and inland), grey alder, and pine forests, aspen, birch, and willow stands; broadleaved and coniferous wayside trees; old military constructions (granite and concrete); old wooden posts and boats on seashore. DH, IS, LK (H, GZU, LECB; Stepanchikova et al., 2010b, 2014; Pykälä et al., 2012; Himelbrant et al., 2015; Red..., 2018). Territories investigated by others

10 (same as 5). Old trees, alleys; deciduous and coniferous forests; anthropogenic habitats. N. V. Malysheva (Malysheva et al., 1995).

11 (same as 7). Pine, pine-spruce, spruce, birch-spruce, black alder forests; glade in forest; seashore communities; roadside trees; anthropogenic habitats. O. A. Kataeva (LE; Kataeva, 2002, 2004; Red..., 2018).

12 Kurortny District, Ik, former Finnish socken Terijoki, Komarovo (Kellomäki), [60¹1'N, 2948’E]. S. V. Sokolova (Sokolova, 1995).

13 Primorsky District, between Lisy Nos and Ol'gino, [6001'N, 3001-06'E]. Malysheva (Malysheva, 1993).

2007, 2011, 2013, 2016, 2019

2010, 2016 2008, 2009, 2012, 2016 1994

2001, 2002 
14 Kurortny District, Ik, former Finnish socken Terijoki, Repino (Kuokkala), [60¹0’N, 2952’E]. Kataeva, Maly- 1995,2017 sheva (LE; Malysheva, 1999, 2003).

15 Kurortny District, Ik, former Finnish socken Terijoki, Solnechnoe (Ollila), [60¹0’N, 2956’E]. A. M. Bat'uk, 1996 O. M. Grishkun (LECB).

16 Kurortny District, Ik, former Finnish socken Terijoki, Zelenogorsk (Terijoki). Park on seashore and roadside trees; pine and spruce forests; anthropogenic habitats. T. Ahti, Malysheva, Sokolova (LE; Sokolova, 1995; Malysheva, 2003, 2005).

Historically studied territories (in 1893-1979)

17 Kurortny District, Ik, former Finnish socken Terijoki, between Sestroretsk and Solnechnoe (former Ollila), Sestroretskye Duny Proposed PA, [6006-07’ N, 29 $\left.{ }^{\circ} 57-58^{\prime} \mathrm{E}\right]$ (same with territory 6). Pine forests on dunes, open slopes of dunes. I. A. Beketov, V. A. Dubyansky, A. A. Elenkin (LE; Savicz, 1910; Dubyansky, 1910, 1919; Elenkin, 1912; Elenkin \& Beketov, 1919).

18 Kurortny District, Ik, former Finnish socken Terijoki, NW vicinities of Zelenogorsk (Terijoki), Käkösenpää, [60¹2’N, 2940’E]. Coniferous forests. S. Ahlner, L. Fagerström (H; Fagerström, 1945; Ahlner, 1948; Hakulinen, 1962a; Vitikainen, 1968).

19 Kurortny District, Ik, former Finnish socken Terijoki, E part of Komarovo (Kellomäki), Kanerva, [60 $11^{\prime} \mathrm{N}$, $\left.29^{\circ} 50^{\prime} \mathrm{E}\right]$. Fagerström (Vitikainen, 1994 (map); H).

20 (same as 12). Pine forests. Ahlner, Fagerström, E. N. Moiseeva, E. Shtukenberg, H. Trass, Zolotareva (H, LE, S, TU; Fagerström, 1945; Ahlner, 1948; Moiseeva, 1959, 1961; Halonen et al., 1999).

21 Primorsky District, Lakhta, [59 $59^{\prime} \mathrm{N}, 30^{\circ} 10^{\prime} \mathrm{E}$ ]. Pine forests on dunes, aspen-pine-birch forest; granite boulders; anthropogenic habitats. Elenkin, B. O. Kashmensky, K. A. Rassadina, V. P. Savicz, N. V. Shipchinsky (LE, S, UPS; Elenkin, 1901, 1904; Verteitinov \& Kashmensky, 1907; Elenkin \& Beketov, 1919; Savicz, 1921; Ahti, 1966; Sokolova, 1995; Malysheva, 2003; Gagarina \& Konoreva, 2015).

22 Primorsky District, between Lakhta and Lisy Nos, [59 $59^{\prime}-60^{\circ} 01^{\prime} \mathrm{N}, 30^{\circ} 01-10^{\prime} \mathrm{E}$ ]. Seashore. Beketov, Elenkin,, I. A. Vereitinov (Vereitinov, 1906; Elenkin \& Beketov, 1919).

23 Primorsky District, between Lakhta and Razdel'naya, [59 $\left.59^{\prime}-60^{\circ} 01^{\prime} \mathrm{N}, 30^{\circ} 01-10^{\prime} \mathrm{E}\right]$. Deciduous-spruce forests, pine forests on dunes. Beketov, Elenkin (LE; Elenkin, 1904; Elenkin \& Beketov, 1919).

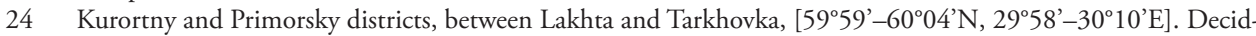
uous-spruce forests (drained and swampy). Beketov, Elenkin (Elenkin \& Beketov, 1919).

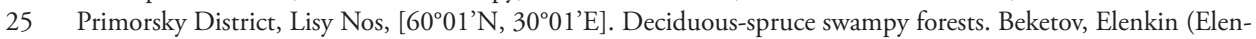
kin \& Beketov, 1919).

26 Kurortny District, Ik, former Finnish socken Uusikirkko, Molodezhnoe (Metsäkylä), [60¹2’N, 29³0’E]. Moiseeva (Moiseeva, 1959, 1961).

27 Primorsky District, Ol'gino, [60 $\left.01^{\prime} \mathrm{N}, 30^{\circ} 06^{\prime} \mathrm{E}\right]$. Pine and spruce forests; seashore and inland granite boulders. Elenkin, Rassadina, Savicz (LE; Savicz, 1921; Malysheva, 2003).

28 Kurortny District, Ik, former Finnish socken Terijoki, Solnechnoe (Ollila), [60¹0'N, 2956'E]. Evrikhov, I. Hiitonen, Shalyapina (H, LE).

29 Kurortny District, Ik, former Finnish socken Terijoki, E part of Zelenogorsk (Terijoki), Ollinpää, [60¹2’N, $\left.29^{\circ} 43^{\prime} \mathrm{E}\right]$. Roadside trees. Fagerström (H; Fagerström, 1945; Hakulinen, 1962a; Vitikainen, 1968, 1994).

30 Kurortny District, Ik, former Finnish socken Terijoki, vicinity of former Rajajoki railway station, $\left[60^{\circ} 08^{\prime} \mathrm{N}\right.$, $29^{\circ} 59^{\prime}$ E]. Pine forests. Fagerström, I. Tikhomirova (H; Fagerström, 1945; Ahlner, 1948; Hakulinen, 1962a).

31 Kurortny District, Ik, former Finnish socken Terijoki, between Sestra River and Repino (Kuokkala), [60 $08^{\circ}$ $\left.10^{\prime} \mathrm{N}, 29^{\circ} 53-59^{\prime} \mathrm{E}\right]$. Fagerström (Fagerström, 1945).

32 Primorsky District, former Razdel'naya railway station near Lisy Nos, [6001’ N, 3001'E]. Elenkin (Elenkin, 1904).

33 (same as 14). Deciduous, pine and mixed forests, dwarf pine forests on peatbogs, dunes, seashore, anthropogenic habitats. Fagerström, Kashmensky, M. Laurila, B. Lemberg, K. S. Mereschkowsky, L. Räsänen, V. Räsänen, R. Tuomikoski, Vereitinov, N. N. Voronikhin (H, LE, S; Mereschkowsky, 1906, 1913; Vereitinov \& Kashmensky, 1907; Savicz, 1910; Elenkin \& Petrov, 1919; Lemberg, 1933, 1935; Fagerström, 1940, 1945; Sokolova, 1995; Malysheva, 2003).

34 Kurortny District, Ik, former Finnish socken Uusikirkko, vicinity of Serovo (Vammelsuu), probably Glady-

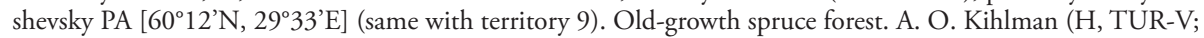
Vainio, 1922, 1927, 1934; Alava, 1988; Stepanchikova et al., 2014).

35 Kurortny District, Sestroretsk, [6006’ N, 295’E]. Elenkin, H. Lindberg, Rassadina, Savicz, Vereitinov (H, LE; Elenkin, 1904, 1906; Vereitinov, 1906; Malysheva, 2003).

36 Kurortny District, Tarkhovka, Glinyany stream mouth, [6004'N, 2958'E]. A. P. Il'insky (LE).

37 Kurortny District, Ik, former Finnish socken Terijoki, [60 $12^{\prime} \mathrm{N}, 29^{\circ} 45^{\prime} \mathrm{E}$ ]. Pine forests, peatbogs, anthropogenic habitats. Fagerström, I. A. Shapiro (H; Fagerström, 1945).

38 Kurortny District, Ik, former Finnish socken Terijoki, Zelenogorsk (Terijoki), [60 $\left.12^{\prime} \mathrm{N}, 2^{\circ}{ }^{\circ} 42^{\prime} \mathrm{E}\right]$. Pine and spruce forests, parks, anthropogenic habitats. Ahlner, Fagerström, E. F. Florovskaya, E. Nilson, L. Räsänen, Savicz, Shtukenberg (H, LE, S, TU; Fagerström, 1945; Vitikainen, 1968, Savicz, 1972). 